\title{
Measurement and Verification of Integrated Ground Source Heat Pumps on a Shared Ground Loop
}

\author{
Jeong Soo Shin ${ }^{1}$, Jong Woo Park ${ }^{1}$ and Sean Hay Kim ${ }^{2, *}$ \\ 1 J\&G Co., Ltd., Jeonju 55070, Korea; syn2989@jngpower.co.kr (J.S.S.); jong3878@jngpower.co.kr (J.W.P.) \\ 2 School of Architecture; Seoul National University of Science \& Technology; Seoul 01811, Korea \\ * Correspondence: seanhay.kim@seoultech.ac.kr
}

Received: 24 February 2020; Accepted: 27 March 2020; Published: 6 April 2020

\begin{abstract}
We propose an integrated geothermal system that consists of air-conditioning and hot water service ground source heat pumps, both of which share a ground water loop. The proposed system increases the COP of the service hot water ground source heat pump by recovering the condensation heat of the air-conditioning ground source heat pump as an evaporator heat source for the hot water service ground source heat pump. Eventually this integration expands the scope and capacity of the evaporator source in addition to the underground water of heat exchangers, which also leads to increase the COP of the air-conditioning ground source heat pump. The integrated geothermal heat pump system was installed in a hotel, and then data were measured for a limited period due to the hotel's ongoing business activities. A TRNSYS simulation model has been developed as a baseline, and the baseline has been calibrated with the measured data. By running one-year simulations, it turns out that the annual electricity use for heating and cooling, and service hot water was reduced by $19.1 \%$ in the cooling season, and by $9.6 \%$ in the heating season, with respect to the conventional configuration in which the air-conditioning heat pump and hot water service heat pump work individually on their own ground loops.
\end{abstract}

Keywords: integrated ground source heat pumps; shared ground loop; waste heat recovery; multiheat pumps; measurement and verification

\section{Introduction}

Ground source heat pumps take advantage of ground thermal sources whose energy level is almost permanent throughout the year. The hot and humid summers, and cold and dry winters of Korea, and resulting unbalanced building demands over the year, however, can seriously unbalance the ground thermal energy when ground source heat pumps keep working for catching up to the peak load. Consequently, geothermal systems for cooling or heating often require a larger ground heat exchanger, which may be restricted by the construction site layout and the initial cost [1].

Nevertheless, as the leaving water that returns to the ground from a typical ground source heat pump is at $20-30{ }^{\circ} \mathrm{C}$ in the cooling season and $0-15^{\circ} \mathrm{C}$ during the heating season in Korea (Figure 1), the waste heat from ground source heat pumps is certainly a more preferred energy source for utilization in cooling and heating than outside heater or chiller air so sharing a water loop and letting a heat rejecter and/or supplemental heaters recover the energy of the leaving water-instead of discharging it to the ground-should be technically, economically, and environmentally encouraged.

Cases of sharing water loops between, in particular, ground source heat pumps and/or heat engines are found in largely two categories: hybrid heat pump systems and multiple heat pump systems. 


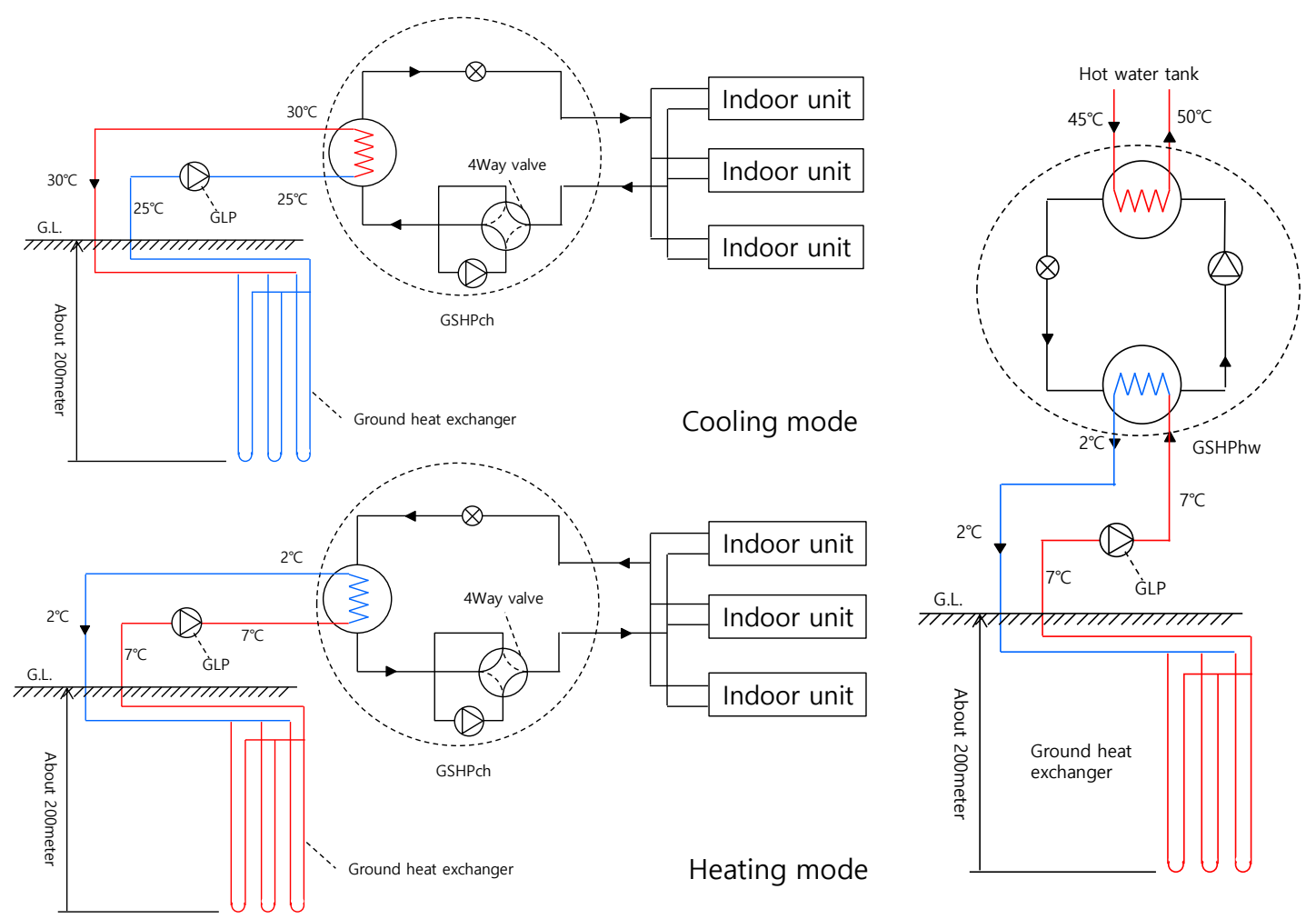

Figure 1. Domestic conventional configuration of $\mathrm{GSHP}_{\mathrm{ch}}$ (left) and $\mathrm{GSHP}_{\mathrm{hw}}$ (right).

Hybrid ground source heat pump systems integrate ground source heat pumps and auxiliary heat rejecters (including cooling towers, fluid coolers, pavement heating systems) or supplemental heat sources (including solar collectors, boilers). The two most common applications in buildings include cooling tower-supplemented ground source heat pumps and solar-assisted ground source heat pump systems.

Conventional open-circuit cooling towers sharing ground water loops with heat pumps reject heat to the air. Based on the heating loads, therefore, the boreholes can be sized smaller than in a conventional ground source system. The cooling tower-supplemented geothermal heat pump is able to closely balance the heat rejected and extracted for the ground heat exchangers over the year, which eventually results in lower initial and operation costs [2-4].

Solar-assisted geothermal heat pump systems are particularly suited for heating-dominant buildings. The solar collectors may supply heat directly to a domestic hot water tank, increase the fluid temperature of the heat pump evaporators, and recharge the boreholes [5]. The ground heat exchanger therefore can be sized to meet the cooling load, and the supplemental solar energy takes case of the excess heat load that is beyond the capacity of the ground heat exchanger. Solar-assisted heat pump systems also demonstrate reduced first and operation costs in general [6-9].

Multiple ground source heat pumps systems share ground water loops between multiple heat pumps, and provide heating, cooling, and service hot water depending on functional combinations of heat pumps.

In the UK, the term "shared ground loop" refers to a communal ground loop that is connected to two or more heat pumps in separate buildings. For rural and restoration areas, it is thought to be a district heating infrastructure alternative. The idea of sharing ground loops is backed up by the reasoning that a loop of twice the size will not cost as much as two separate loops, and will be more resilient as it is unlikely that the demands of two buildings will always happen at identical times [10]. Additionally, the UK Renewable Heat Incentive (RHI) has made the payment for heat pumps in domestic properties on the shared ground loops typically be based on the deemed heat demand of the whole property [11], which has promoted installing the shared ground loops in many UK facilities. 
As multiple heat pumps with different demands in different buildings are attached to the shared ground loop, Alavy et al. [12] mentioned that the load imbalance between the heating and cooling demands of ground heat pumps sharing a common ground loop would eventually result in longer ground heat exchangers to meet peak heating and cooling loads. Therefore, intelligent combinations and configurations of heating-dominant buildings and cooling-dominant buildings $[13,14]$ can reduce the length of the required ground loop, and the total costs as well.

Domestically, several multiple ground source heat pump cases are reported as follows:

Choi et al. [15] have shown experimentally that multiple ground source heat pumps were able to maintain a uniform and stable temperature distribution in a greenhouse, compared to conventional heating systems. Under partial load conditions, however, the system COP dropped due to the larger ground water flows needed and the resulting pumping power increase. They recommend developing new controls for optimizing ground circulation flow rates.

Jung et al. [16] proposed a sequential operation of multiple ground source heat pumps, all of which concurrently service heating and cooling for a hospital. Compared to the legacy operation where all ground source heat pumps equally serve the load, the sequential operation reduced the annual energy use by approximately $40 \%$, because if just only several heat pumps take charge of the partial load, unwanted partial load operations of all heat pumps with lower COPs can be avoided.

Shin et al. [17] has proposed an ANN (Artificial Neural Network)-based variable water flow rate control system for multiple ground source heat pumps. By controlling the flow rate proportional to the temperature difference between EWT and LWT, the circulating water supply flow rate was reduced, and this made the circulating pumping power decrease as well.

To summarize the relevant studies and practices, in hybrid ground source heat pump systems, the heat pump shares its condenser leaving the water loop with heat rejecters such as cooling towers, and shares the evaporator leaving water loop with supplemental heaters such as solar collectors. Even though compensating the peak loads with auxiliary devices reduces the length of the ground heat exchanger and increases the operation COP, the increased system complexity may cause difficulties in realizing optimal system design and operational controls [18].

In multiple ground source heat pump systems, it is possible that the heat pumps be attached to the ground loop, but physically located in different buildings, and they may not work for the same demand, while heat pumps attached to the ground loop and also located in the same building work for the same demand. If some heat pumps in the former configuration seriously break the load balance, the resulting performance degradation would impact all the heat pumps attached to the shared ground loop, because there seems to be no effective way to control the rest of the heat pumps located on someone else's property, so unless the ground source heat pumps in different buildings are centrally monitored and controlled, and likewise any variable air volume systems, disturbance and control issues cannot be avoided.

\section{Research Objectives}

A number of newly built large buildings in Korea have a diverse lineup of plant systems; the list of popular plant systems includes chillers, boilers, district heat exchangers, ground source heat pumps, water heaters, and thermal energy storage systems. For many of those buildings, however, innovative combinations of hybrid plant systems are seldom tried, and instead predefined combinations of plant systems serve the designated zones. For instance, while lobby and common areas are serviced by ground source heat pumps, the rest of the functional spaces are serviced by chillers and heat exchangers. This design convention is also applied to air handlers and terminals.

When hybrid systems are installed, building service managers' concerns over faulty detection and dynamic controls, and the lack of experienced operators often justify the resistance to hybrid systems. In particular, for small and mid-sized buildings where monitoring systems are very simply configured, or which have limited functions, service managers typically tend to go for conventional HVAC (Heating, Ventilation, Air Conditioning) configurations with little deliberation. 
In the UK, the technical superiority, sustainability, and economics of the shared ground loop generally spread over, and thus social and legal consensus on the ownership and operational responsibility of the shared ground loop have been settled. In South Korea, however, for now it seems not possible to accept the ground loop shared by different facilities, although its technical superiority is easily understood. For domestic small and mid-sized buildings where ground source heat pumps are installed for heating and cooling, it is a frequent case that service water heaters such as gas boilers or electric water heaters are installed separately. If a higher renewable energy ratio is necessary in a building by regulation, which is in fact very often the case, another ground source heat pump for service hot water is independently installed on its own ground loop (Figure 1).

Despite the domestic practice that favors separated ground loops per separate demand type (i.e., no mixed demands served by a single group of ground heat exchangers), constructing ground loops for every type of building demands, even more for every new installation of heat pumps should be a redundant investment, and would have far less utility. Hence we suggest a balance between the custom and the innovation, namely, an integrated geothermal heat pump system where both the air-conditioning heat pumps and service hot water heat pumps share the ground heat exchanger, while both heat pumps offer services to the same building.

This "integrated" heat recovery is similar to the mechanism of cascading; when super-low or super-high temperature "refrigerants" are obtained by placing a cascade or two-level heat exchangers within a heat pump, and then it directly transferring the condensation heat of the low-temperature side refrigerant to the evaporator of the high-temperature side refrigerant. The integrated heat recovery, however, reuses the outlet "water" from one heat pump as the heat source of another heat pump. Reusing the low-temperature fluid for the high-temperature heat engine is specifically feasible for heat pumps. Indeed, heat pumps in particular are good for low-temperature waste heat recovery, as they provide the capability to upgrade waste heat to a higher temperature and quality $[19,20]$. This claim was, for instance, demonstrated in [21]; the heat pumps deliver 2.5-11 times more energy value than the power cycles in the low temperature range of $45-60{ }^{\circ} \mathrm{C}$, at equal waste heat input.

The underlying development idea of the proposed system is that in summer, the condensation heat of the air-conditioning ground source heat pumps can be reused by hot water ground source heat pumps. If both ground source heat pumps discard the evaporation heat into the ground in winter, however, the ground temperature may drop significantly. Then by sequence controls or by some advanced controls, the full load operation by both heat pumps can be avoided. Eventually the integrated geothermal system is able to reduce the ground loop length sizing for smaller peak loads, while increasing the system COP.

The developed system was installed in an actual hotel in Korea. This study aims to demonstrate the enhanced performance by experiments, and to analyze how much annual energy use can be saved. Lastly the research team plans to develop optimal controls for the developed system, and to demonstrate the control in the test site. However, as data acquisition is limited due to the ongoing business operations and the presence of guests, a sufficiently long term dataset (e.g., all year around data) cannot be obtained. Instead this study aims to execute Measurement and Verification (M\&V) phase [22-24], and a TRNSYS [25] baseline model has been constructed and then calibrated by the measured data, but collected over a limited period. Eventually the increased system COPs and saved electricity consumption were compared to the base case.

\section{Principle and Process of the Integrated Ground Source Heat Pumps on the Shared Ground Loop}

As shown in Figure 2, when GSHP ${ }_{\text {ch }}$ operates in cooling mode, the water at the design temperature at approximately $24^{\circ} \mathrm{C}$ from the ground heat exchanger passes through three-way valve \#2 (full valve opening) and enters the condenser inlet of $\mathrm{GSHP}_{\mathrm{ch}}$. The water is then heated up by the refrigerant at the condenser, and is discharged at approximately $30^{\circ} \mathrm{C}$. The water at $30^{\circ} \mathrm{C}$ passes through three-way valve \#1 (fully closed), flows into the evaporator of $\mathrm{GSHP}_{\mathrm{hw}}$, and then heats up the refrigerant of the 
evaporator. Finally, it is approximately at design temperature of $27^{\circ} \mathrm{C}$ when the water leaves the evaporator, and goes back to the ground heat exchanger.

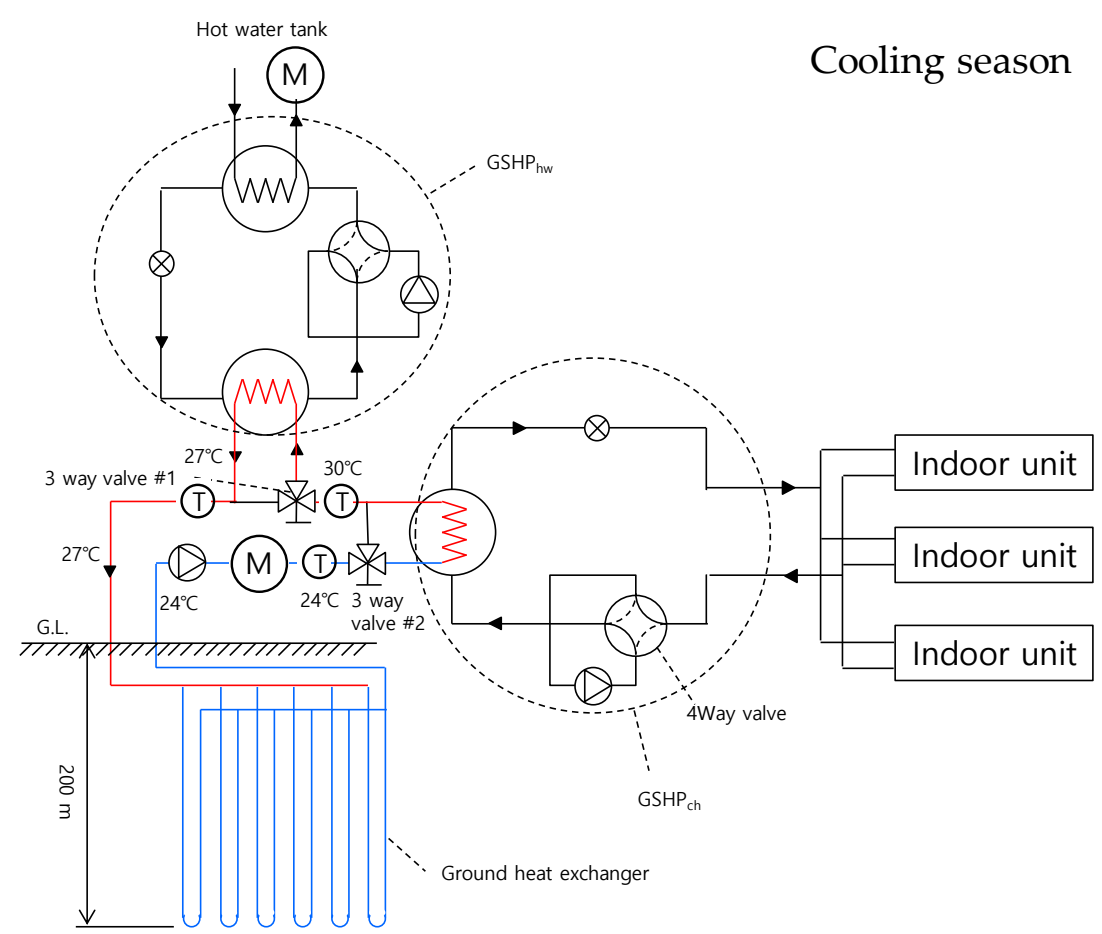

(a)

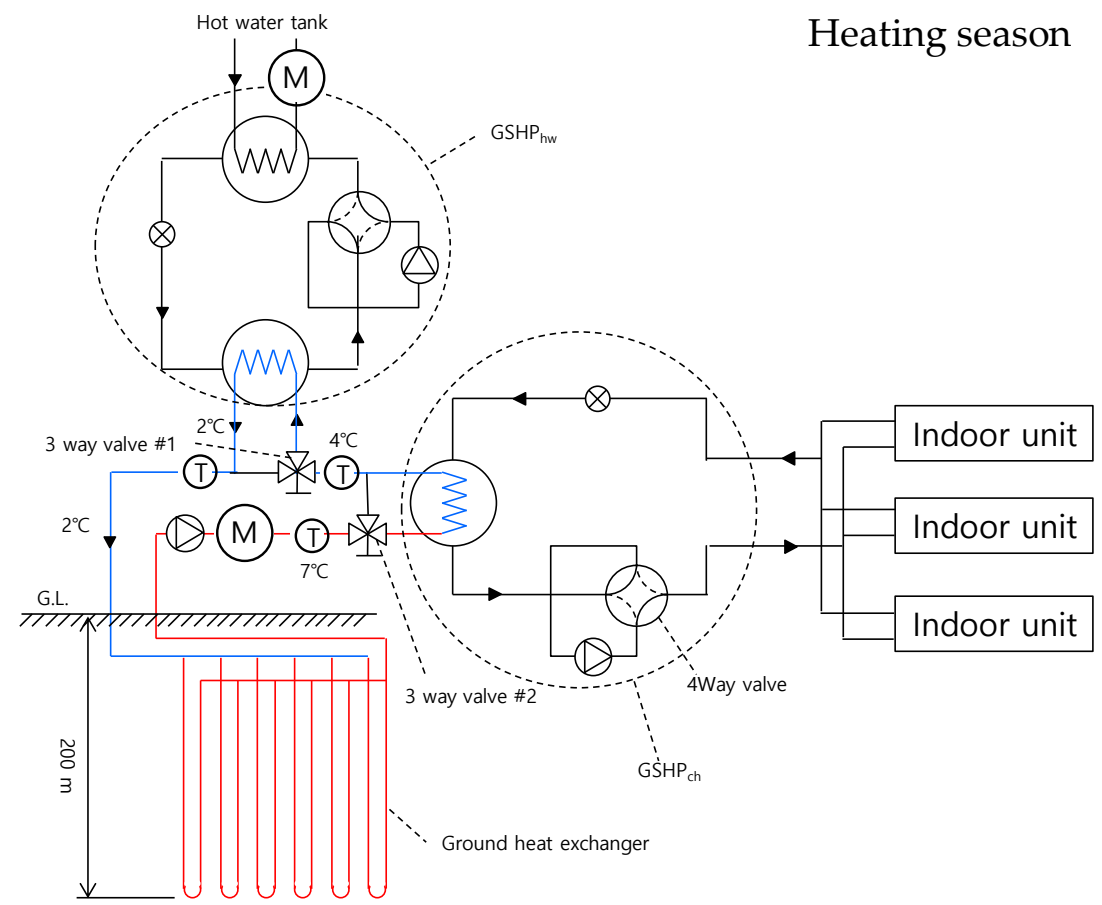

(b)

Figure 2. (a) The integrated geothermal heat pump system in cooling season (top); (b) The integrated geothermal heat pump system in cooling season in heating season (bottom); (M) denotes flow meter and $(\mathrm{T})$ denotes thermowell.

Considering the reference design EWT of general SHW ground source heat pumps is $7{ }^{\circ} \mathrm{C}$, when warmer water of approximately $30^{\circ} \mathrm{C}$ enters the evaporator of $\mathrm{GSHP}_{\mathrm{hw}}$, the $\mathrm{COP}_{\mathrm{hw}}$ should increase; 
because the compression ratio of the compressor can be reduced despite the same required condensation temperature. In other words, as the evaporation temperature line on the P-h diagram of GSHP $\mathrm{hw}_{\text {in }}$ Figure 3 rises (from line 4-1 to line $4^{\prime}-1^{\prime}$ ), the power required for the compressor for the same required condensation temperature decreases from a to b. Consequently, the COP of $\mathrm{GSHP}_{\mathrm{hw}}\left(\mathrm{COP}_{\mathrm{hw}}\right)$ can increase as much.

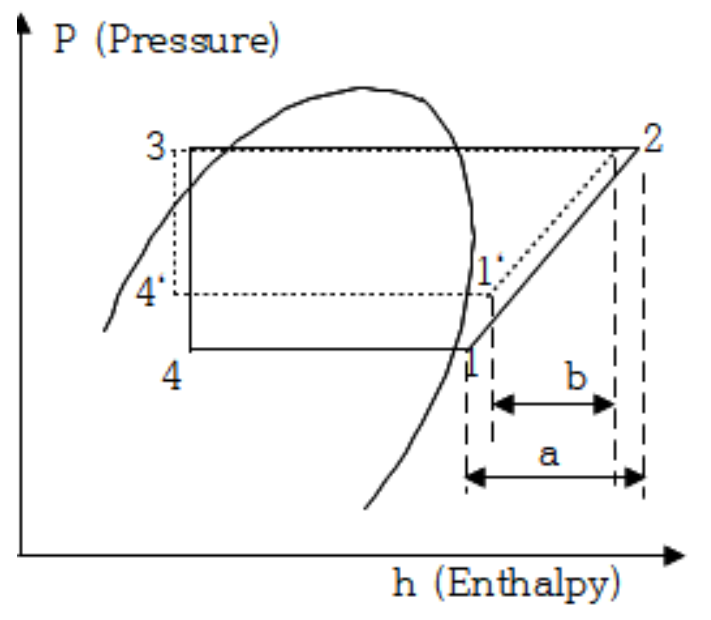

Figure 3. P-h diagram of $\mathrm{GSHP}_{\mathrm{hw}}$.

Also the evaporator of $\mathrm{GSHP}_{\mathrm{hw}}$ as cooling source is added to the ground heat exchanger to which $\mathrm{GSHP}_{\mathrm{ch}}$ discards the condensation heat. In the P-h diagram of $\mathrm{GSHP}_{\mathrm{ch}}$ in Figure 4, the condensation line descends from 2-3 to $2^{\prime}-3^{\prime}$. At the same time, the compression ratio for the same required evaporation temperature decreases from $\mathrm{c}$ to $\mathrm{d}$, and the evaporation capacity increases from $\mathrm{e}$ to $\mathrm{f}$. As a result, the cooling COP of $\mathrm{GSHP}_{\mathrm{ch}}\left(\mathrm{COP}_{\mathrm{c}}\right)$ can increase as well.

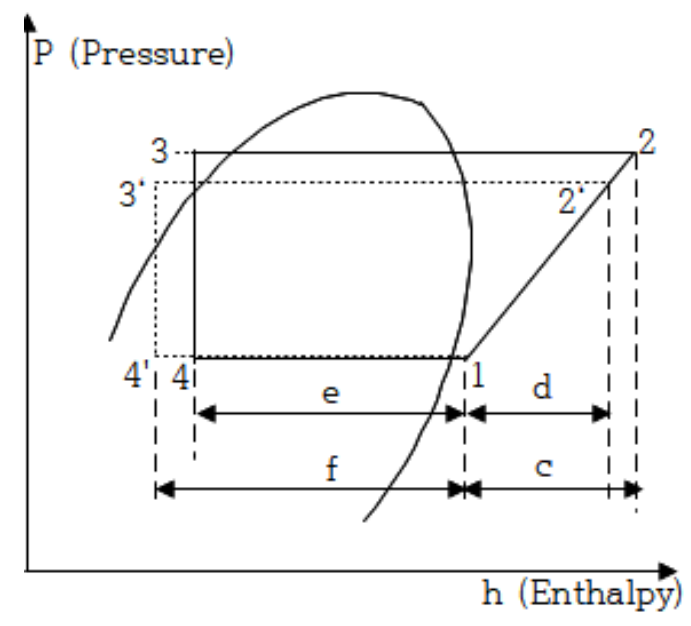

Figure 4. P-h diagram of $\mathrm{GSHP}_{\mathrm{ch}}$.

Along with increased COP of $\mathrm{GSHP}_{\mathrm{hw}}$ and $\mathrm{GSHP}_{\mathrm{ch}}$ in cooling mode, the pumping power also can be reduced significantly because only a single pump (GLP) is good enough for circulating all the water over the shared ground water loop.

When both $\mathrm{GSHP}_{\mathrm{ch}}$ and GSHP $\mathrm{hw}_{\mathrm{w}}$ operate in heating mode, the ground water at the design temperature of approximately $7{ }^{\circ} \mathrm{C}$ is supplied to the evaporator of $\mathrm{GSHP}_{\mathrm{ch}}$, and it exits the GSHP $\mathrm{ch}$ evaporator at the design temperature of $4^{\circ} \mathrm{C}$. Through the three-way valve \#1 in Figure 2 (fully closed), the water eventually enters the evaporator of $\mathrm{GSHP}_{\mathrm{hw}}$. After the water absorbs the evaporation heat, its (design) temperature is supposed to drop to approximately $2{ }^{\circ} \mathrm{C}$, and then returns to the ground 
heat exchanger. According to domestic practices for operating ground source heat pumps, it is advised to mix approximately $13-20 \%$ of antifreeze (ethyl alcohol) with the ground loop water in order to prevent freezing, thus the ground loop water seldom freeze at around $2{ }^{\circ} \mathrm{C}$. By analyzing 20 year ground temperature profiles, nevertheless, Ground Loop Design [26] has verified the resilience even when $\mathrm{LWT}_{\mathrm{hw}}$ drops to $0{ }^{\circ} \mathrm{C}$.

In the heating operation, since both $\mathrm{GSHP}_{\mathrm{ch}}$ and $\mathrm{GSHP}_{\mathrm{hw}}$ share the ground heat exchanger, the entire ground water in the heat exchanger absorbs evaporation heat from both heat pumps when under full load operations and/or partial load operations. In this case, the ground water temperature would not be as fluctuating as the ground water temperature in case each $\mathrm{GSHP}_{\mathrm{ch}}$ and $\mathrm{GSHP}_{\mathrm{hw}}$ has their own (smaller) ground heat exchangers. This integration, therefore, works as a larger heat buffer that mitigate over-chilling of evaporators for both heat pumps, which signifies if $\mathrm{GSHP}_{\mathrm{ch}}$ and $\mathrm{GSHP}_{\mathrm{hw}}$ operate in sequence holding a sufficient pause in-between, ground water would be able to keep a relatively stable temperature. Also the pumping power can be reduced significantly in the heating operation likewise, because single pump (ground loop pump in Figure 2) is just sufficient to circulate the ground loop water.

\section{Experiment}

\subsection{Experiment Configuration}

The proposed system was installed in a hotel having $6150 \mathrm{~m}^{2}$ of floor area, which is located in Daegu, South Korea. Three water-to-air heat pumps (GSHP $\mathrm{ch}$ ) and one SHW heat pump $\left(\mathrm{GSHP}_{\mathrm{hw}}\right)$ share the ground water loop. Three $\mathrm{GSHP}_{\mathrm{ch}}$ 's provide heating and cooling for $2500 \mathrm{~m}^{2}$ of floor area including public space such as conference halls, restaurants, and fitness club and showers. Table 1 lists the specifications of the ground source heat pump systems installed at the test site.

Table 1. Test site configuration and system specification.

\begin{tabular}{|c|c|c|}
\hline \multicolumn{2}{|c|}{ System Equipment } & Description and Specification \\
\hline \multirow{4}{*}{$\mathrm{GSHP}_{\mathrm{ch}}$} & \multirow{2}{*}{$\begin{array}{l}\text { Water-Air cooling } \\
\qquad(\mathrm{R} 410 \mathrm{a})\end{array}$} & $\begin{array}{c}69 \mathrm{~kW} \times 2 \mathrm{EA}\left(\mathrm{GSHP}_{\mathrm{ch}}-1\right)+21 \mathrm{~kW} \times 1 \mathrm{EA} \\
\left(\mathrm{GSHP}_{\mathrm{ch}}-2\right)\end{array}$ \\
\hline & & Rated COP: 5.07 \\
\hline & \multirow[t]{2}{*}{$\begin{array}{l}\text { Water-Air heating } \\
\qquad(\mathrm{R} 410 \mathrm{a})\end{array}$} & $\begin{array}{c}75 \mathrm{~kW} \times 2 \mathrm{EA}\left(\mathrm{GSHP}_{\mathrm{ch}}-1\right)+22 \mathrm{~kW} \times 1 \mathrm{EA} \\
\left(\mathrm{GSHP}_{\mathrm{ch}}-2\right)\end{array}$ \\
\hline & & Rated COP: 4.66 \\
\hline \multirow{2}{*}{$\mathrm{GSHP}_{\mathrm{hw}}$} & \multirow{2}{*}{$\begin{array}{l}\text { Water-Water heating } \\
\text { (R410a) }\end{array}$} & $184 \mathrm{~kW} \times 1 \mathrm{EA}\left(\mathrm{GSHP}_{\mathrm{hw}}\right)$ \\
\hline & & Rated COP: 3.92 \\
\hline \multicolumn{2}{|c|}{ Ground loop pump } & $4 \mathrm{~kW} \times 1 \mathrm{EA}(11.7 \mathrm{~kg} / \mathrm{s})$, variable speed \\
\hline \multicolumn{2}{|c|}{ Bore holes } & $200 \mathrm{~m} \times 24$ holes $\times \Phi 0.15$ \\
\hline \multicolumn{2}{|c|}{ Ground heat exchanger } & HDPE, 40A, SDR-11 \\
\hline
\end{tabular}

To calculate COP of heat pumps, data acquisition instruments were attached at the required data points of the water pipes as shown as Figure 2. Table 2 lists the measurement devices. Since $\mathrm{GSHP}_{\text {ch }}$ uses R410a refrigerant at the demand side, it is difficult to directly measure heating and cooling loads serviced by GSHP ${ }_{\text {ch }}$. Thus, a flowmeter was installed at the inlet of the source side, and thermowells for measuring the temperature difference were installed at both the inlet and outlet points. Then the heating and cooling system load is calculated based on measured flow rates and temperature difference. For $\mathrm{GSHP}_{\mathrm{hw}}$, a flow meter was installed at the inlet of the demand side, and thermowells for measuring the temperature difference were installed at both the inlet and outlet points; such that hot water demand served by $\mathrm{GSHP}_{\mathrm{hw}}$ is calculated directly. All the data started to be collected for 2 weeks from 20th October 2017, and recoded at every one minute. Due to interruptions (e.g., by 
on-site guests) and stand-by for steady state, however, effective collections were actually much shorter than two weeks.

Table 2. Measurement devices and their specification.

\begin{tabular}{|c|c|c|c|}
\hline \multicolumn{2}{|c|}{ Instruments } & \multirow{2}{*}{$\begin{array}{c}\text { Specification } \\
\text { Manufacturer: Ultrasonics Maxiflo } \\
\text { Range: } 0-16 \mathrm{~m} / \mathrm{s} \\
\text { Repeatability: } \pm 0.2-0.5 \% \\
\text { Output: } 4-20 \mathrm{~mA}\end{array}$} & \multirow{2}{*}{$\begin{array}{l}\text { Accuracy } \\
\pm 0.5 \sim 1 \%\end{array}$} \\
\hline $\begin{array}{c}\text { Water } \\
\text { properties }\end{array}$ & Flow meter & & \\
\hline & Thermowell & $\begin{array}{c}\text { Manufacturer: GINICE KOREA } \\
\text { Sensor: } \mathrm{Pt} 100 \Omega \\
\text { Range: }-30-150^{\circ} \mathrm{C}\end{array}$ & $\pm 0.3{ }^{\circ} \mathrm{C}$ \\
\hline \multirow[t]{2}{*}{ Airproperties } & Thermometer & $\begin{array}{l}\text { Manufacturer: Testo } \\
\text { Repeatability: } \pm 0.1 \% \\
\text { Range: }-10-50{ }^{\circ} \mathrm{C}\end{array}$ & $\pm 0.5^{\circ} \mathrm{C}$ \\
\hline & Humidity meter & $\begin{array}{c}\text { Manufacturer: Testo } \\
\text { Repeatability: } \pm 0.1 \% \mathrm{RH} \\
\text { Range: } 0-100 \% \mathrm{RH}\end{array}$ & $\pm 2.5 \% \mathrm{RH}$ \\
\hline \multicolumn{2}{|c|}{$\begin{array}{c}\text { Power meter } \\
\text { (Voltage, Current, Power) }\end{array}$} & $\begin{array}{c}\text { Manufacturer: CET } \\
\text { KWH Class: IEC 62053-21:2003 Class1 }\end{array}$ & $\pm 0.5 \%$ \\
\hline
\end{tabular}

\subsection{Measurement of the Integrated Geothermal System for Cooling and Service Hot Water}

All the experiments were performed when construction was just complete, thus the hotel is open for business. Since the experiment was carried out during a changing season when the building cooling load was typically lower, the cooling load was intentionally manipulated using portable heaters and humidifiers to ensure a constant temperature and humidity. However, the hot water load is always there because hotels require hot water all the time.

Since the hotel was operating normally, the operation state of both heat pumps could also be transient due to varying weather conditions and fluctuating guests. Therefore, keeping a sufficiently long term steady-state operation with a constant temperature and flow rate was somehow difficult. For the time being, however, we had reserved the window where a relatively steady state is maintained. The temperature and flow rate measured during the experiment were recorded for every one minute by data loggers. The heat pump system load can be calculated as Equation (1):

$$
\dot{q}=\dot{m} c_{p} \Delta t
$$

where $\dot{q}$ denotes the system load served by heat pump (W); $\dot{m}$ denotes the water mass flow rate $(\mathrm{kg} / \mathrm{s}) ; c_{p}$ denotes the specific heat of the water $(\mathrm{J} / \mathrm{K} \cdot \mathrm{kg}) ; \Delta \mathrm{t}$ denotes the temperature difference between entering water and leaving water $(\mathrm{K})$.

Even though the ground loop water contains about $13 \%$ alcohol, the properties of pure water were used in the COP calculation instead. Thus $4.19 \mathrm{~kJ} / \mathrm{kg} \cdot{ }^{\circ} \mathrm{C}$ and $999.0 \mathrm{~kg} / \mathrm{m}^{3}$ were used as the specific heat and density of the loop water, respectively. The system COP of GSHP ${ }_{c h}\left(C O P_{c s}\right)$ and the system COP of $\mathrm{GSHP}_{\mathrm{hw}}\left(\mathrm{COP}_{h w w s}\right)$ were calculated using the system load and the measured power consumption as specified by equations (2) and (3):

$$
\begin{aligned}
& C O P_{h w s}=\frac{\int_{1}^{t} \dot{q}_{d}(t) d t}{\int_{1}^{t} W_{h w}(t) d t+\int_{1}^{t} W_{g l p}(t) d t} \\
& C O P_{c s}=\frac{\int_{1}^{t} \dot{q}_{s}(t) d t-\int_{1}^{t} W_{c h}(t) d t}{\int_{1}^{t} W_{c h}(t) d t+\int_{1}^{t} W_{g l p}(t) d t}
\end{aligned}
$$


where $\dot{q}_{d}$ denotes the demand-side load $(\mathrm{W}) ; \dot{q}_{s}$ denotes the supply-side load $(\mathrm{W}) ; W_{h w}$ denotes the power consumed by $\mathrm{GSHP}_{\mathrm{hw}}(\mathrm{W}) ; W_{c h}$. denotes the power consumed by $\mathrm{GSHP}_{\mathrm{ch}}(\mathrm{W}) ; W_{g l p}$ denotes the power consumed by GLP (W)

As shown in Equation (2) above, the system COP of $\mathrm{GSHP}_{\mathrm{hw}}$ can be directly calculated by measuring the water flow rate supplied to the demand side, temperature difference, and power consumption. However, the system load of $\mathrm{GSHP}_{\mathrm{ch}}$ is difficult to obtain from the demand side. Thus the system's cooling COP of GSHP ${ }_{\text {ch }}\left(C O P_{c s}\right)$ was calculated using Equation (3), where $\dot{q}_{s}$ actually refers to the condensation load used for cooling operation, and $W_{c h}$ refers to the compression power. That is, $\dot{q}_{s}-W_{c h}$. corresponds to a majority of evaporation heat, assuming other auxiliary power losses are negligible.

Finally, the data were collected when $\mathrm{GSHP}_{\mathrm{ch}}$ operates for cooling and when $\mathrm{GSHP}_{\mathrm{hw}}$ operates for SHW, separately. After that, the data were collected when both heat pumps operate together (i.e., heat recovery operation) as if in a cooling season.

\subsection{Measurement of the Integrated Geothermal System for Heating and Service Hot Water}

The heating experiment was performed under the same configuration described in Section 4.2 in terms of the instruments, composition of the experimental setup, and experimental method. However, the room temperature was adjusted to a constant value while adjusting the portable cooler and dehumidifier. The experiment data were firstly collected when $\mathrm{GSHP}_{\mathrm{ch}}$ operates for heating, and when $\mathrm{GSHP}_{\mathrm{hw}}$ operates for SHW, separately. Then the data were collected when both heat pumps operate together (i.e., concurrent operation) as if in heating season.

Meanwhile the system's heating COP of GSHP $\mathrm{ch}_{\mathrm{ch}}\left(\mathrm{COP}_{\mathrm{hs}}\right)$ were calculated using Equation (4) where $\dot{q}_{s}$ actually refers to the evaporation load used for heating operation. That is, $\dot{q}_{s}+W_{c h}$ corresponds to a majority of condensation heat, assuming other auxiliary power losses are negligible:

$$
\mathrm{COP}_{h s}=\frac{\int_{1}^{t} \dot{q}_{s}(t) d t+\int_{1}^{t} W_{c h}(t) d t}{\int_{1}^{t} W_{c h}(t) d t+\int_{1}^{t} W_{g l p}(t) d t}
$$

\subsection{Experiment Results}

To compare the performance of the integrated geothermal system, conventional individual heat pumps need to be tested as well. Individual operation tests were alternated by taking turns between $\mathrm{GSHP}_{\mathrm{ch}}$ and $\mathrm{GSHP}_{\mathrm{hw}}$, but activating only the number of ground heat exchangers, which correspond to the capacity of the running heat pumps (by closing the valve for the rest of the heat exchangers). All the test process is elaborated in Figure 5.

Since the test hotel was actually in use, it was difficult to maintain the steady state of the fluid in the system (e.g., water, air, refrigerant) for a sufficiently long term. Therefore, the experimental data began to be recorded when the system reached a relatively steady state sometime after starting the experiment. That is, all the data started to be calculated after at least one or two hours later than when EWT and LWT of the ground source heat pump maintained a relatively stable state. 


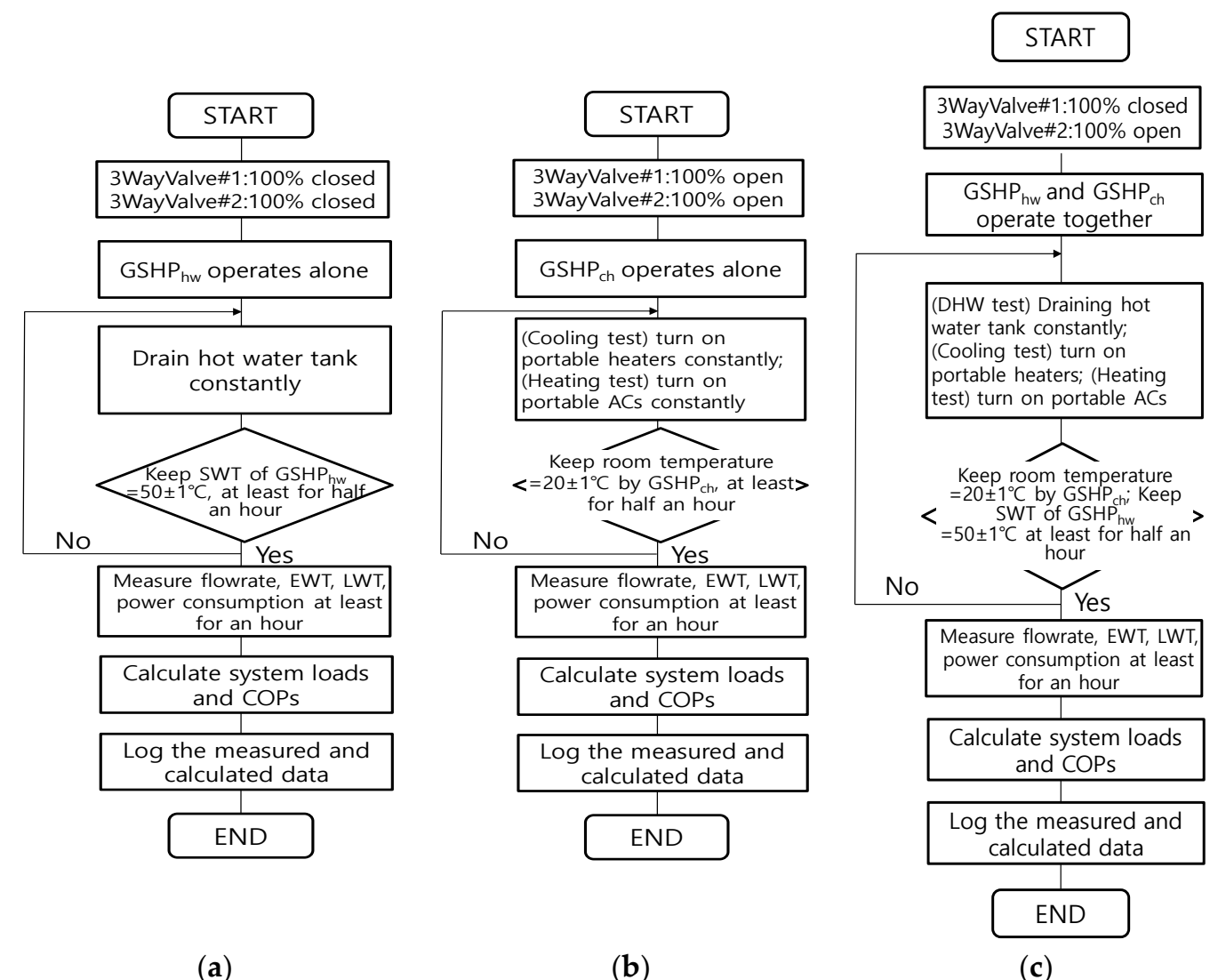

Figure 5. (a) testing process of $\mathrm{GSHP}_{\mathrm{hw}}$ for supplying SHW (left); (b) testing process of $\mathrm{GSHP}_{\mathrm{ch}}$ for heating or cooling (middle); (c) testing process of concurrently operating both $\mathrm{GSHP}_{\mathrm{hw}}$ and $\mathrm{GSHP}_{\mathrm{ch}}$ (right).

\subsubsection{When the Heat Recovery Operation for Cooling and Setarvice Hot Water}

The GSHP ${ }_{h w}$ and GSHP ch operates alone one by one (Figure 5a,b). Though their EWTs were within a similar range when experiments start over, EWTs and LWTs at the steady state reach at different values as heat balances are made independently. At the steady state, the flow rate of the entering water was about $9.2 \mathrm{~kg} / \mathrm{s}$ for each heat pump. Also they have shown increasing trends for cooling and decreasing trends for hot water.

Next the GSHP $\mathrm{hw}_{\mathrm{w}}$ operates alone at first (Figure 5a), and then the $\mathrm{GSHP}_{\mathrm{ch}}$ joined for waste heat recovery while activating all the ground heat exchangers (Figure $5 \mathrm{c}$ ). As increasing the entering water flow rate to the evaporator of $\mathrm{GSHP}_{\mathrm{hw}}$ by closing the three-way valve \#1 by up to $100 \%$ (completely closed), the data were collected at an average interval of one minute in a quasi-steady state for at least one to two hours. As a result of the waste heat recovery, the $\mathrm{EWT}_{\mathrm{hw}}$ of the $\mathrm{GSHP}_{\mathrm{hw}}$ increased from $14.10^{\circ} \mathrm{C}$ up to $15.20^{\circ} \mathrm{C}$. Consequently, the average $\mathrm{COP}_{\text {hws }}$ of the $\mathrm{GSHP}_{\mathrm{hw}}$ increased up to 3.37 (Table 3).

Additionally, when the $\mathrm{GSHP}_{\mathrm{ch}}$ operates alone for cooling first (Figure 5b), and then the $\mathrm{GSHP}_{\mathrm{hw}}$ joined for it (Figure $5 \mathrm{c}$ ), the average $\mathrm{COP}_{\mathrm{cs}}$ of the $\mathrm{GSHP}_{\mathrm{ch}}$ increased up to 4.55 (Table 3).

By activating all the ground heat exchangers for the heat recovery operation, the capacity of the ground heat source for both heat pumps has increased. Thereafter, $\mathrm{EWT}_{\mathrm{ch}}$ of the GSHP $\mathrm{ch}$ decreased after heat balance is made, which has increased the heat release to ground, and thus finally has improved the $\mathrm{COP}_{\mathrm{cs}}$.

It should be noted that during heat recovery operation, the GLP circulates the entire ground loop water through both heat pumps. Therefore, calculation of $\mathrm{COP}_{\mathrm{hws}}$ and $\mathrm{COP}_{\mathrm{cs}}$ accounts for only partial pumping power that is consumed to deliver the water to $\mathrm{GSHP}_{\mathrm{hw}}$ and $\mathrm{GSHP}_{\mathrm{ch}}$, respectively. 
Table 3. Ranges of EWT, LWT and COP of GSHP $\mathrm{hw}_{\mathrm{w}}$ and $\mathrm{GSHP}_{\mathrm{ch}}$ during cooling and SHW test.

\begin{tabular}{|c|c|c|c|}
\hline \multicolumn{2}{|c|}{ Cooling and SHW } & $\begin{array}{c}\text { Individual Operation } \\
\text { Range (Average) }\end{array}$ & $\begin{array}{c}\text { Heat Recovery Operation } \\
\text { Range (Average) }\end{array}$ \\
\hline \multirow{3}{*}{$\mathrm{GSHP}_{\mathrm{hw}}$} & $\mathrm{EWT}_{\mathrm{hw}}$ & $\begin{array}{c}10.50-11.20^{\circ} \mathrm{C} \\
\left(10.81^{\circ} \mathrm{C}\right)\end{array}$ & $\begin{array}{l}14.10-15.20^{\circ} \mathrm{C} \\
\left(14.63{ }^{\circ} \mathrm{C}\right)\end{array}$ \\
\hline & $\mathrm{LWT}_{\mathrm{hw}}$ & $\begin{array}{c}7.60-8.50{ }^{\circ} \mathrm{C} \\
\left(8.01{ }^{\circ} \mathrm{C}, \Delta \mathrm{T}=-2.8 \mathrm{~K}\right)\end{array}$ & $\begin{array}{c}12.80-14.10^{\circ} \mathrm{C} \\
\left(13.45^{\circ} \mathrm{C}, \Delta \mathrm{T}=-1.18 \mathrm{~K}\right)\end{array}$ \\
\hline & $\mathrm{COP}_{\text {hws }}$ & $\begin{array}{c}2.34-2.66 \\
(2.53)\end{array}$ & $\begin{array}{c}2.82-3.66 \\
(3.37)\end{array}$ \\
\hline \multirow{3}{*}{$\mathrm{GSHP}_{\mathrm{ch}}$} & $\mathrm{EWT}_{\mathrm{ch}}$ & $\begin{array}{l}14.00-15.10^{\circ} \mathrm{C} \\
\left(14.62{ }^{\circ} \mathrm{C}\right)\end{array}$ & $\begin{array}{l}12.80-14.10^{\circ} \mathrm{C} \\
\left(13.44{ }^{\circ} \mathrm{C}\right)\end{array}$ \\
\hline & $\mathrm{LWT}_{\mathrm{ch}}$ & $\begin{array}{c}15.90-17.00^{\circ} \mathrm{C} \\
\left(16.51^{\circ} \mathrm{C}, \Delta \mathrm{T}=1.89 \mathrm{~K}\right)\end{array}$ & $\begin{array}{c}14.10-15.20^{\circ} \mathrm{C} \\
\left(14.63^{\circ} \mathrm{C}, \Delta \mathrm{T}=1.19 \mathrm{~K}\right)\end{array}$ \\
\hline & $\mathrm{COP}_{\mathrm{cs}}$ & $\begin{array}{l}3.70-4.18 \\
(3.95)\end{array}$ & $\begin{array}{l}4.00-5.85 \\
(4.55)\end{array}$ \\
\hline
\end{tabular}

$\Delta \mathrm{T}$ equals to the average of LWT minus the average of EWT.

\subsubsection{When the Concurrent Operation for Heating and Service Hot Water}

Likewise, when GSHP $\mathrm{ch}_{\mathrm{ch}}$ operates alone for heating and then reaches at the steady state, $\mathrm{EWT}_{\mathrm{ch}}$ and $\mathrm{LWT}_{\mathrm{ch}}$ have shown a decreasing trend. Note that the $\mathrm{EWT}_{\mathrm{ch}}$ for heating become starts to be stabilized at around $13^{\circ} \mathrm{C}$, meanwhile the $\mathrm{EWT}_{\mathrm{ch}}$ for cooling starts to be stabilized at around $14{ }^{\circ} \mathrm{C}$, which is slightly higher than the $\mathrm{EWT}_{\mathrm{ch}}$ for heating; it is because even though both heating and cooling tests start over at a similar range of EWTs, higher EWT is advantageous for making a stable cooling performance.

For the concurrent operation test, the $\mathrm{GSHP}_{\mathrm{hw}}$ operates alone at first (Figure 5a), and then the $\mathrm{GSHP}_{\mathrm{ch}}$ joined for it (Figure 5c). Then it was repeated again until they reach at the steady state. As the $\mathrm{EWT}_{\mathrm{hw}}$ keeps around $12.0{ }^{\circ} \mathrm{C}$, the $\mathrm{COP}_{\mathrm{hws}}$ of the $\mathrm{GSHP}_{\mathrm{hw}}$ maintains a range between 3.05 and 3.47 (Table 4). Next the GSHP ${ }_{\text {ch }}$ operates alone for heating first (Figure $5 b$ ), and then the GSHP ${ }_{h w}$ joined for it (Figure 5c). The $\mathrm{COP}_{\mathrm{hs}}$ of the $\mathrm{GSHP}_{\mathrm{ch}}$ then keeps around 2.93 (Table 4).

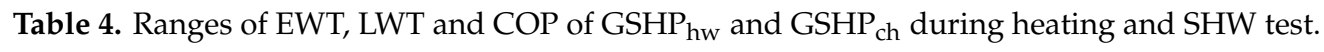

\begin{tabular}{|c|c|c|c|}
\hline \multicolumn{2}{|c|}{ Heating and SHW } & $\begin{array}{l}\text { Individual Operation } \\
\text { Range (Average) }\end{array}$ & $\begin{array}{l}\text { Concurrent Operation } \\
\text { Range (Average) }\end{array}$ \\
\hline \multirow{3}{*}{$\mathrm{GSHP}_{\mathrm{hw}}$} & $\mathrm{EWT}_{\mathrm{hw}}$ & $\begin{array}{l}10.50-11.20^{\circ} \mathrm{C} \\
\left(10.81{ }^{\circ} \mathrm{C}\right)\end{array}$ & $\begin{array}{c}12.00-12.20^{\circ} \mathrm{C} \\
\left(12.15^{\circ} \mathrm{C}\right)\end{array}$ \\
\hline & $\mathrm{LWT}_{\mathrm{hw}}$ & $\begin{array}{c}7.60-8.50^{\circ} \mathrm{C} \\
\left(8.01^{\circ} \mathrm{C}, \Delta \mathrm{T}=-2.8 \mathrm{~K}\right)\end{array}$ & $\begin{array}{c}9.90-10.20^{\circ} \mathrm{C} \\
\left(10.06^{\circ} \mathrm{C}, \Delta \mathrm{T}=-2.09 \mathrm{~K}\right)\end{array}$ \\
\hline & $\mathrm{COP}_{\text {hws }}$ & $\begin{array}{l}2.34-2.66 \\
(2.53)\end{array}$ & $\begin{array}{c}3.05-3.47 \\
\quad(3.30)\end{array}$ \\
\hline \multirow{3}{*}{$\mathrm{GSHP}_{\mathrm{ch}}$} & $\mathrm{EWT}_{\mathrm{ch}}$ & $\begin{array}{c}12.00-13.40^{\circ} \mathrm{C} \\
\left(12.66^{\circ} \mathrm{C}\right)\end{array}$ & $\begin{array}{c}13.30-13.50{ }^{\circ} \mathrm{C} \\
\left(13.43^{\circ} \mathrm{C}\right)\end{array}$ \\
\hline & $\mathrm{LWT}_{\mathrm{ch}}$ & $\begin{array}{c}10.60-12.60{ }^{\circ} \mathrm{C} \\
\left(11.13^{\circ} \mathrm{C}, \Delta \mathrm{T}=-1.53 \mathrm{~K}\right)\end{array}$ & $\begin{array}{c}12.00-12.20^{\circ} \mathrm{C} \\
\left(12.15^{\circ} \mathrm{C}, \Delta \mathrm{T}=-1.28 \mathrm{~K}\right)\end{array}$ \\
\hline & $\mathrm{COP}_{\mathrm{hs}}$ & $\begin{array}{c}2.66-2.95 \\
(2.85)\end{array}$ & $\begin{array}{c}2.77-3.00 \\
(2.93)\end{array}$ \\
\hline
\end{tabular}

$\Delta \mathrm{T}$ equals to the average of LWT minus the average of EWT. 
By activating all the ground heat exchangers for the concurrent operation, the capacity of the ground heat source has increased; the flow rate of the entering water was about $11.3 \mathrm{~kg} / \mathrm{s}$. Since the $\mathrm{GSHP}_{\mathrm{ch}}$ first consumes larger volume of ground water, the $\mathrm{EWT}_{\mathrm{ch}}$ of the $\mathrm{GSHP}_{\mathrm{ch}}$ has increased. Then the increased $\mathrm{EWT}_{\mathrm{ch}}$ results in higher $\mathrm{LWT}_{\mathrm{ch}}$ and higher $\mathrm{EWT}_{\mathrm{hw}}$ than those of the individual operation. Also the pumping power has reduced for the concurrent operation. These two causalities eventually have increased the $\mathrm{COP}_{\mathrm{hws}}$ compared to that of the individual operation.

\section{Simulation-Based Measurement and Verification}

$\mathrm{M} \& \mathrm{~V}$ assesses the annual power savings by the integrated geothermal heat pumps on the shared ground loop with respect to the conventional individual operation of each heat pump. Since the test hotel was a newly completed hotel, no annual operation data could be acquired. Furthermore, as guests were staying in the hotel, the cooling and heating, and hot water supply loads have been instantly varying, it was difficult to maintain a steady state of the fluid circulating the system for a sufficiently long duration. Due to measurement limitations and unavailability of long-term data, the research team determined that simulation-based $M \& V$ is more appropriate than $M \& V$ based on data driven models (e.g., regressions) [27,28]. Finally, the base simulation model was constructed using TRNSYS as depicted in Figure 6.

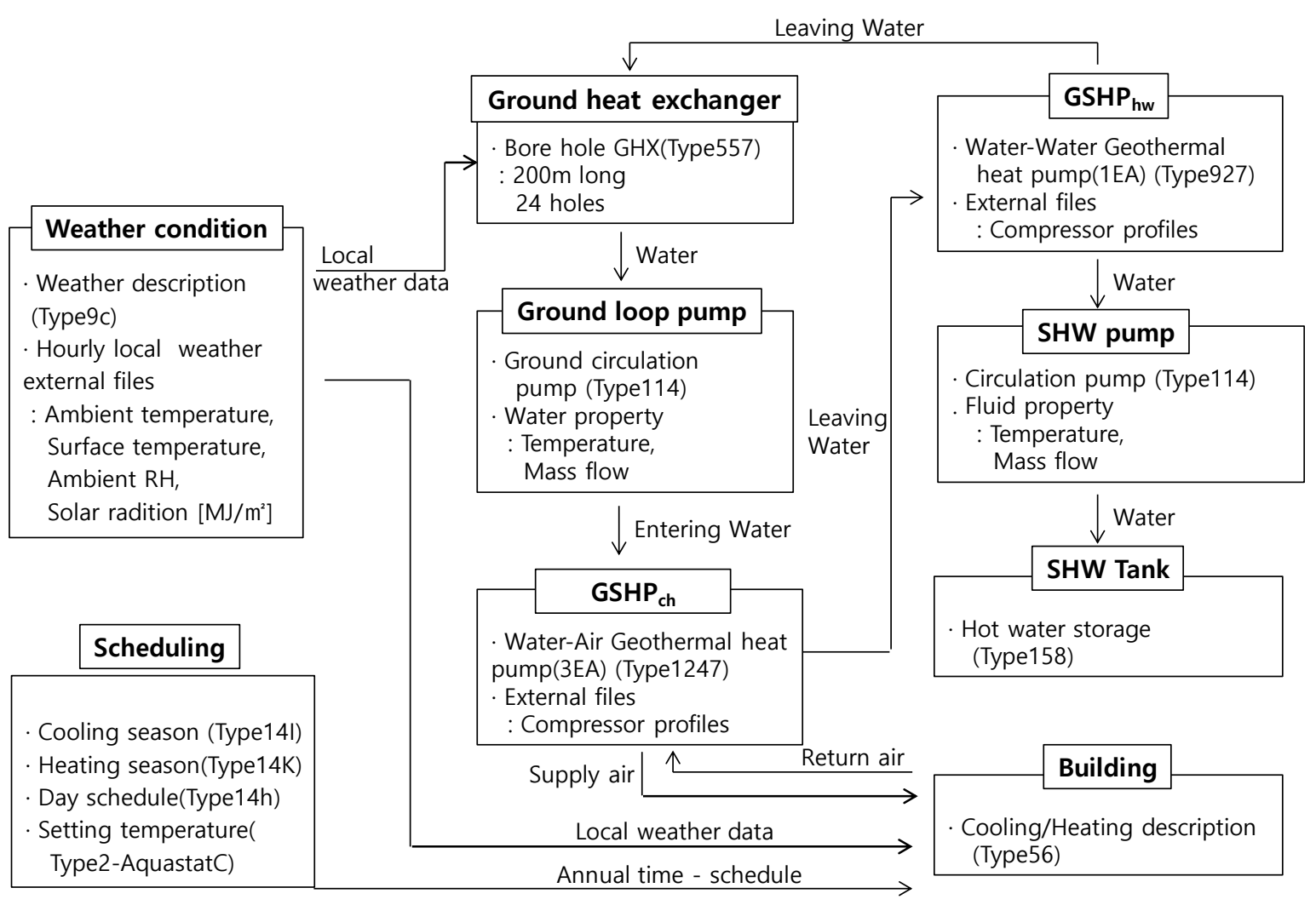

Figure 6. TRNSYS configuration featuring primary components.

\subsection{Baseline Model}

The weather data (ambient temperature and humidity, solar radiation, and etc.) were downloaded from the Korea Meteorological Administration. The hotel to which the integrated geothermal heat pump system was installed was modeled in 3D; external and internal walls, windows, air-conditioned and non-air-conditioned spaces were built. Since only public spaces are serviced by the integrated geothermal system, all other spaces are set to $20^{\circ} \mathrm{C}$ and $50 \%$ of relative humidity as if they are conditioned as determined. Cooling and heating set point temperatures for the public space was set to $20^{\circ} \mathrm{C}$ as well, and SHW set points are $50^{\circ} \mathrm{C}$ for summer and $55^{\circ} \mathrm{C}$ for winter. Daily air-conditioning 
operates from 14 to 23 o'clock per hotel's business plan, and SHW was supplied from 14 to 16 o'clock in cooling season, and from 20 to 23 o'clock in heating season. Ventilation rate was 1.0 air changes per hour $(\mathrm{ACH})$. Internal and external loads (e.g., occupants, equipment, lighting, external infiltration, outdoor air intake) were specified according to the building and system design document.

The properties of primary TRNSYS components are described in Figure 6. The characteristic profiles of capacity and input power according to the condensation temperature of the heat pump were implemented as a capacity curve by referring to manufacturers' catalogue. All other properties not specified in Tables 5 and 6 use the TRNSYS default values.

Table 5. TRNSYS properties of GSHPs.

\begin{tabular}{cccc}
\hline \multicolumn{1}{c}{ GSHP $_{\text {ch }}$ Properties } & \multicolumn{2}{c}{ GSHP $_{\text {hw }}$ Properties } \\
\hline Rated total cooling capacity $(\mathrm{kW})$ & 161 & Rated cooling capacity $(\mathrm{kW})$ & 184 \\
\hline Rated cooling power $(\mathrm{kW})$ & 33.8 & Rated cooling power $(\mathrm{kW})$ & 34 \\
\hline Rated heating capacity $(\mathrm{kW})$ & 172 & Rated heating capacity $(\mathrm{kW})$ & 184 \\
\hline Rated heating power $(\mathrm{kW})$ & 39.1 & Rated heating power $(\mathrm{kW})$ & 39 \\
\hline Rated air flow rate $\left(\mathrm{m}^{3} / \mathrm{h}\right)$ & 27,454 & Rated source flow rate $(\mathrm{l} / \mathrm{s})$ & 10.8 \\
\hline Rated liquid flow rate $(\mathrm{l} / \mathrm{s})$ & 10.8 & Rated load flow rate $(\mathrm{l} / \mathrm{s})$ & 10.8 \\
\hline
\end{tabular}

Table 6. TRNSYS properties of GHX and GLP.

\begin{tabular}{cccc}
\hline \multicolumn{2}{c}{ GHX TRNSYS Properties } & \multicolumn{2}{c}{ GLP TRNSYS Properties } \\
\hline Storage thermal conductivity $(\mathrm{W} / \mathrm{mK})$ & 2.05 & Rated flow rate $(\mathrm{kg} / \mathrm{s})$ & 19.80 \\
\hline Fill thermal conductivity $(\mathrm{W} / \mathrm{mK})$ & 0.92 & Fluid specific heat $(\mathrm{kJ} / \mathrm{kgK})$ & 4.19 \\
\hline $\begin{array}{c}\text { (Ground loop) Pipe thermal } \\
\text { conductivity }(\mathrm{W} / \mathrm{mK})\end{array}$ & 16.40 & Rated power $(\mathrm{kW})$ & 4.00 \\
\hline Reference borehole flow rate $(\mathrm{l} / \mathrm{s})$ & 19.80 & & \\
\hline
\end{tabular}

Furthermore, the conductivity of the borehole ground heat exchanger was obtained by the thermal conductivity test (Table 7) and thermal conductivity equation (Equation 5) according to the line source theory. The temperature of the ground water entering and leaving the borehole over time was measured as shown in Figure 7. Accordingly, the thermal conductivity was determined as $2.05 \mathrm{~W} / \mathrm{mK}$.

$$
k=\frac{Q}{4 \pi \times l \times \Delta T}
$$

where $k$ denotes the effective thermal conductivity of soil and grout mixture $(\mathrm{W} / \mathrm{mK}) ; Q$ denotes heat flow rate $(\mathrm{W}) ; l$ denotes the length of a ground heat exchanger $(\mathrm{m}) ; \Delta T$ denotes the average temperature slope over logarithmic time (K).

Table 7. Thermal conductivity test.

\begin{tabular}{cccc}
\hline Initial temperature $\left({ }^{\circ} \mathrm{C}\right)$ & 14.20 & Heating energy $(\mathrm{J} / \mathrm{s})$ & 11,746 \\
\hline Temperature difference $\left({ }^{\circ} \mathrm{C}\right)$ & 5.81 & Heat loss of water $(\mathrm{J} / \mathrm{s})$ & 11,646 \\
\hline Mass flow $(\mathrm{kg} / \mathrm{s})$ & 0.48 & Borehole depth $(\mathrm{m})$ & 204 \\
\hline Average Voltage $(\mathrm{V})$ & 220.71 & Slope $(\mathrm{a})$ & 2.24 \\
\hline Average Ampere $(\mathrm{A})$ & 53.22 & Thermal conductivity $(\mathrm{W} / \mathrm{mK})$ & 2.05 \\
\hline
\end{tabular}




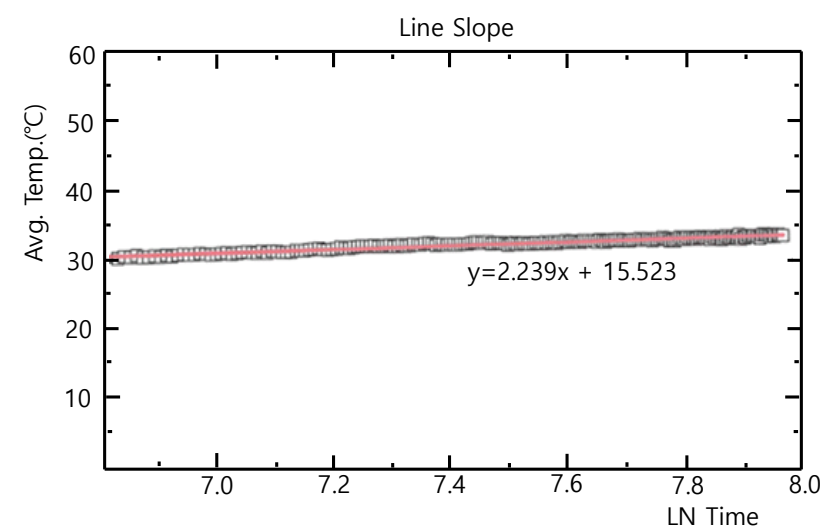

Figure 7. Borehole EWT and LWT during effective thermal conductivity tests of soil and grout mixture.

\subsection{Baseline Model Calibration}

To balance and stabilize the heat of the geothermal environment for our simulation, the simulation was started approximately one month before the actual experiment period. Then the initial values of simulation (e.g., initial surface temperature, source flow rate, load flow rate, heat pump power, and etc.) were calibrated based on the results of the experiment.

In addition, to verify the deviation and fluctuation rate between the actual measurement and the simulation results, the calibrations were evaluated using the Normalized Mean Bias Error (NMBE) and Coefficient of Variation of the Root Mean Square Error (CV-RMSE) as shown in the following Equations (6) and (7). The M\&V guidelines [22-24] recommend less than $\pm 10 \%$ of NMBE and less than $30 \%$ of CV-RMSE for hourly measurement:

$$
\begin{gathered}
\mathrm{NMBE}=\frac{\frac{1}{n} \sum_{i-1}^{n}\left(y_{i}-y_{i}{ }^{\prime}\right)}{\bar{y}} \times 100[\%] \\
\mathrm{CV}-\mathrm{RMSE}=\frac{\sqrt{\frac{1}{n} \sum_{i=1}^{n}\left(y_{i}-y_{i}{ }^{\prime}\right)^{2}}}{\bar{y}} \times 100[\%]
\end{gathered}
$$

where $n$ denotes the number of data set; $y$ denotes the observed data; $y^{\prime}$ denotes the simulated data.

\subsection{Calibration of GSHP ch at the Individual Operation for Cooling and Heating}

Figures 8-10 depict the simulation results and actual observations of $\mathrm{EWT}_{\mathrm{ch}}, \mathrm{LWT}_{\mathrm{ch}}$, and $\mathrm{COP}_{\mathrm{cs}}$, respectively, when $\mathrm{GSHP}_{\text {ch }}$ operates alone for cooling. Table 8 lists up the NMBE and CV-RMSE after calibration. Both indices except for $\mathrm{COP}_{\mathrm{cs}}$ were within $\pm 6 \%$.

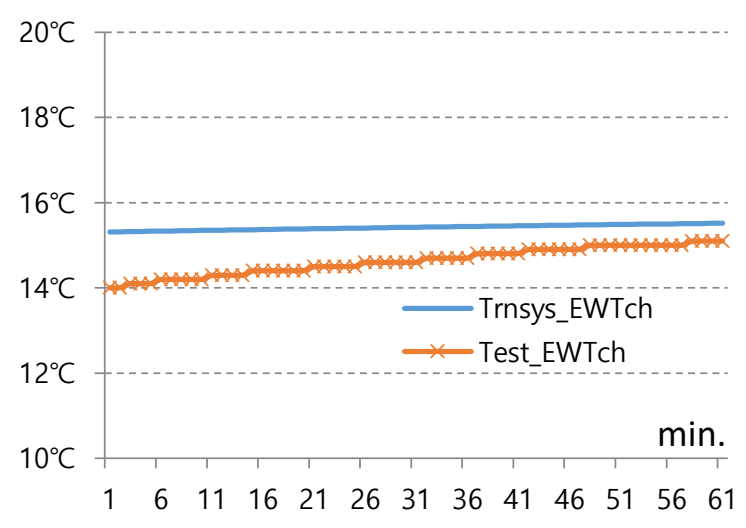

Figure 8. $\mathrm{EWT}_{\mathrm{ch}}$ of the $\mathrm{GSHP}_{\mathrm{ch}}$ for individual cooling. 


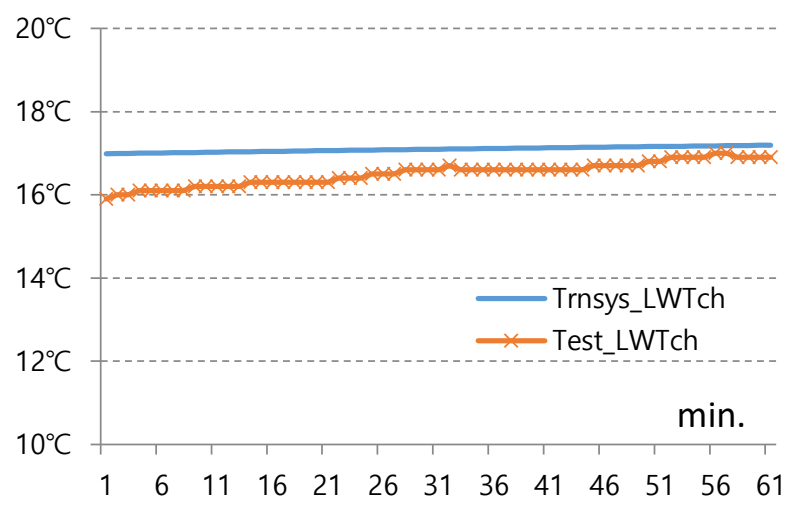

Figure 9. $\mathrm{LWT}_{\mathrm{ch}}$ of the $\mathrm{GSHP}_{\mathrm{ch}}$ for individual cooling.

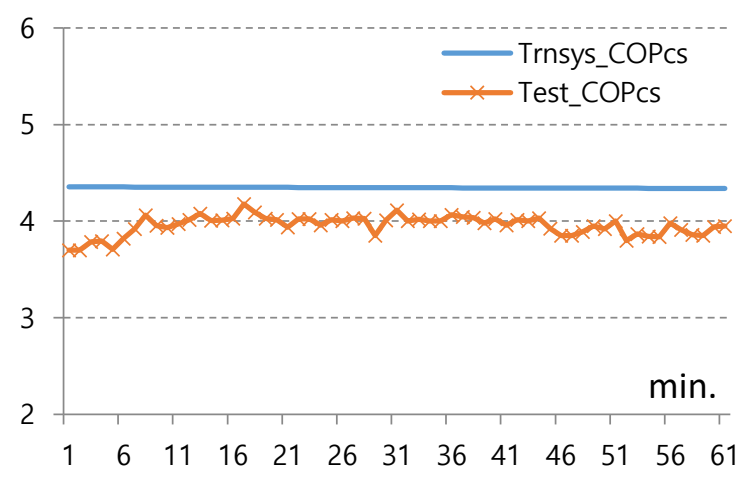

Figure 10. $\mathrm{COP}_{\mathrm{cs}}$ of the $\mathrm{GSHP}_{\mathrm{ch}}$ for individual heating.

Table 8. Simulated vs. measured system COP, LWT and EWT of the GSHP $\mathrm{ch}_{\mathrm{ch}}$ at the individual operation for cooling and heating.

\begin{tabular}{|c|c|c|c|c|c|c|}
\hline \multirow{2}{*}{$\begin{array}{l}\text { Individual } \\
\text { cooling }\end{array}$} & \multicolumn{2}{|c|}{$\mathrm{COP}_{\mathrm{cs}}$} & \multicolumn{2}{|c|}{$\mathrm{LWT}_{\mathrm{ch}}\left({ }^{\circ} \mathrm{C}\right)$} & \multicolumn{2}{|c|}{$\mathrm{EWT}_{\mathrm{ch}}\left({ }^{\circ} \mathrm{C}\right)$} \\
\hline & Simulated & Observed & Simulated & Observed & Simulated & Observed \\
\hline $\begin{array}{l}\text { Range } \\
\text { (avg.) }\end{array}$ & $\begin{array}{c}4.34-4.36 \\
(4.35)\end{array}$ & $\begin{array}{c}3.70-4.18 \\
(3.95)\end{array}$ & $\begin{array}{c}16.99-17.19 \\
(17.09)\end{array}$ & $\begin{array}{c}15.90-17.00 \\
(16.51)\end{array}$ & $\begin{array}{c}15.31-15.52 \\
(15.42)\end{array}$ & $\begin{array}{c}14.00-15.10 \\
(14.62)\end{array}$ \\
\hline NBME & \multicolumn{2}{|c|}{$-9.92 \%$} & \multicolumn{2}{|c|}{$-3.54 \%$} & \multicolumn{2}{|c|}{$-5.42 \%$} \\
\hline CV-RMSE & \multicolumn{2}{|c|}{$10.24 \%$} & \multicolumn{2}{|c|}{$3.79 \%$} & \multicolumn{2}{|c|}{$5.71 \%$} \\
\hline \multirow{2}{*}{$\begin{array}{l}\text { Individual } \\
\text { heating }\end{array}$} & \multicolumn{2}{|c|}{$\mathrm{COP}_{\mathrm{hs}}$} & \multicolumn{2}{|c|}{$\mathrm{LWT}_{\mathrm{ch}}\left({ }^{\circ} \mathrm{C}\right)$} & \multicolumn{2}{|c|}{$\mathrm{EWT}_{\mathrm{ch}}\left({ }^{\circ} \mathrm{C}\right)$} \\
\hline & Simulated & Observed & Simulated & Observed & Simulated & Observed \\
\hline $\begin{array}{l}\text { Range } \\
\text { (avg.) }\end{array}$ & $\begin{array}{c}2.93-2.94 \\
(2.94)\end{array}$ & $\begin{array}{c}2.66-2.95 \\
(2.85)\end{array}$ & $\begin{array}{c}11.16-11.42 \\
(11.28)\end{array}$ & $\begin{array}{c}10.60-12.60 \\
(11.13)\end{array}$ & $\begin{array}{c}12.37-12.64 \\
(12.48)\end{array}$ & $\begin{array}{c}12.00-13.40 \\
(12.66)\end{array}$ \\
\hline NBME & \multicolumn{2}{|c|}{$-3.01 \%$} & \multicolumn{2}{|c|}{$-1.33 \%$} & \multicolumn{2}{|c|}{$1.38 \%$} \\
\hline CV-RMSE & \multicolumn{2}{|c|}{$3.7 \%$} & \multicolumn{2}{|c|}{$4.03 \%$} & \multicolumn{2}{|c|}{$3.39 \%$} \\
\hline
\end{tabular}

Figures 11-13 depict the simulation results and actual observations of $\mathrm{EWT}_{\mathrm{ch}}, \mathrm{LWT}_{\mathrm{ch}}$, and $\mathrm{COP}_{\mathrm{hs}}$, respectively, when $\mathrm{GSHP}_{\mathrm{ch}}$ operates alone for heating. Table 8 lists up the NMBE and CV-RMSE after calibration. Both indices were within $\pm 5 \%$. 


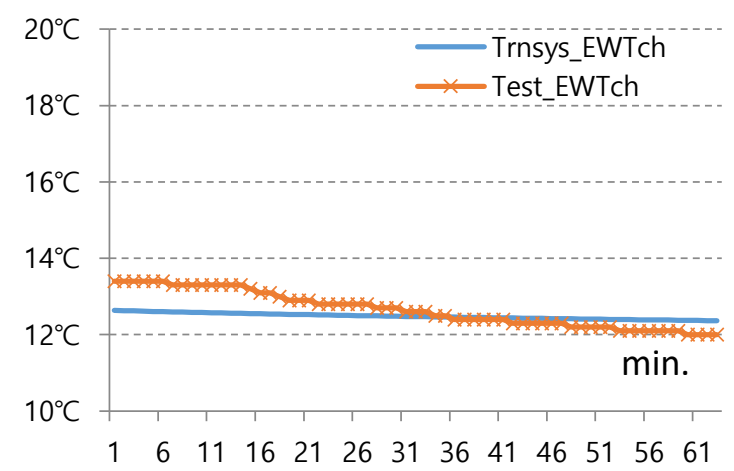

Figure 11. $\mathrm{EWT}_{\mathrm{ch}}$ of the $\mathrm{GSHP}_{\mathrm{ch}}$ for individual heating.

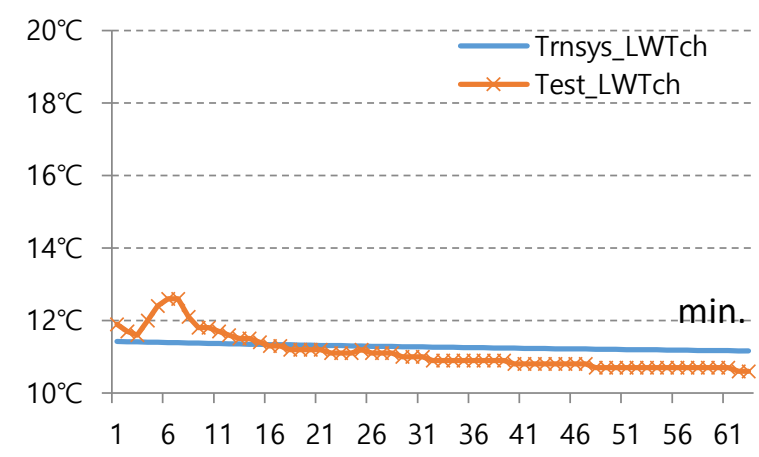

Figure 12. $\mathrm{LWT}_{\mathrm{ch}}$ of the $\mathrm{GSHP}_{\mathrm{ch}}$ for individual cooling.

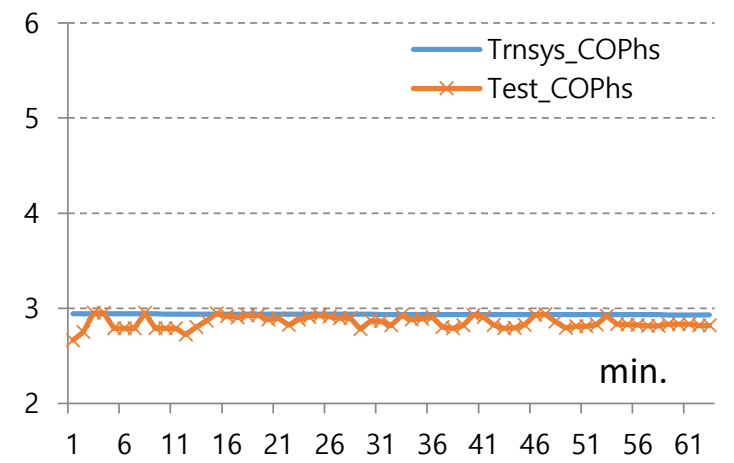

Figure 13. $\mathrm{COP}_{\mathrm{hs}}$ of the $\mathrm{GSHP}_{\mathrm{ch}}$ for individual heating.

\subsection{Calibration of $\mathrm{GSHP}_{h w}$ at the Individual Operation}

Figures 14-16 depict the simulation results and actual observations of $\mathrm{EWT}_{\mathrm{hw}}, \mathrm{LWT}_{\mathrm{hw}}$, and $\mathrm{COP}_{\mathrm{hws}}$, respectively, when the $\mathrm{GSHP}_{\mathrm{hw}}$ operates alone for supplying hot water. Table 9 lists up the NMBE and CV-RMSE after calibration. Both indices except for $\mathrm{LWT}_{\mathrm{hw}}$ were within $\pm 6 \%$. 


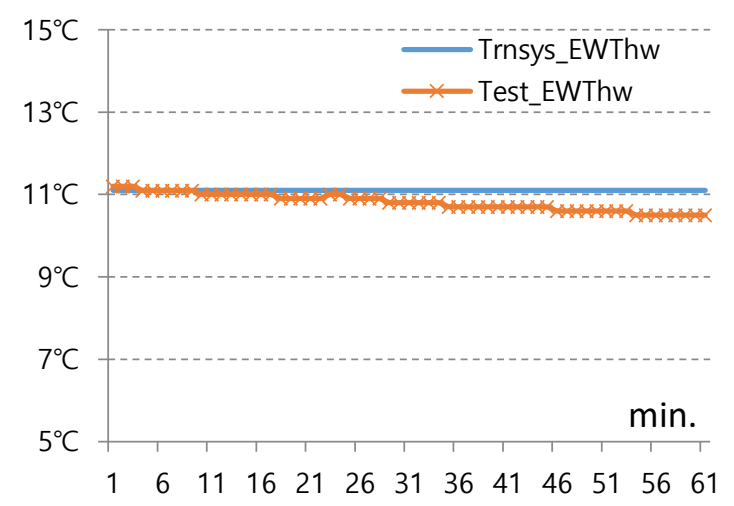

Figure 14. $\mathrm{EWT}_{\mathrm{hw}}$ of the $\mathrm{GSHP}_{\mathrm{hw}}$ for individual hot water.

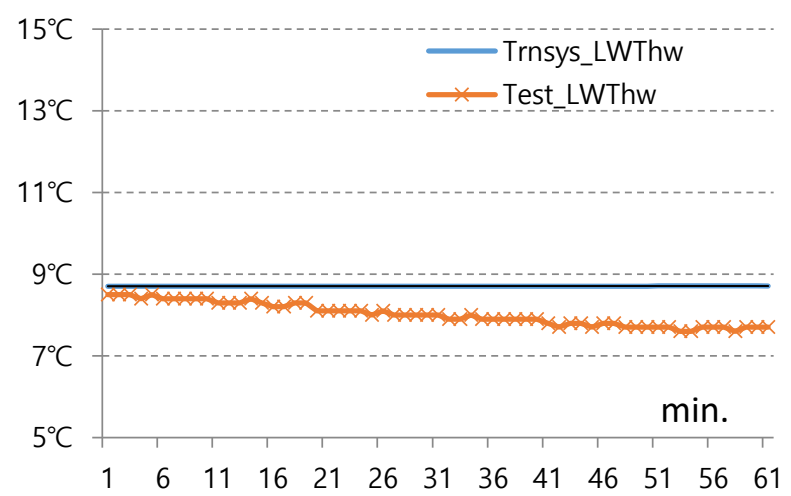

Figure 15. $\mathrm{LWT}_{\mathrm{hw}}$ of the $\mathrm{GSHP}_{\mathrm{hw}}$ for individual hot water.

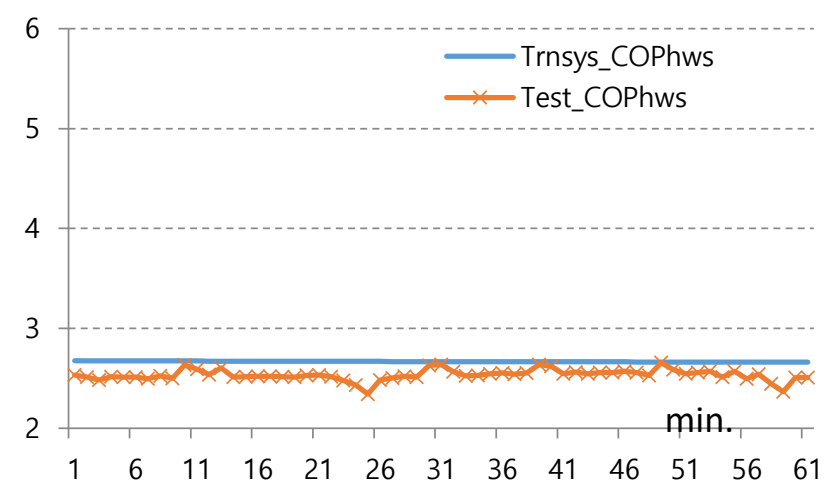

Figure 16. $\mathrm{COP}_{\text {hws }}$ of the $\mathrm{GSHP}_{\mathrm{hw}}$ for individual hot water.

Table 9. Simulated vs. measured system COP, LWT and EWT of the GSHP $\mathrm{hw}_{\text {at }}$ at the individual operation.

\begin{tabular}{ccccccc}
\hline \multirow{2}{*}{$\begin{array}{c}\text { Individual } \\
\text { Operation }\end{array}$} & \multicolumn{2}{c}{$\mathbf{C O P}_{\mathbf{h w s}}$} & \multicolumn{2}{c}{$\mathbf{L W T}_{\mathbf{h w}}\left({ }^{\circ} \mathbf{C}\right)$} & \multicolumn{2}{c}{$\mathrm{EWT}_{\mathbf{h w}}\left({ }^{\circ} \mathbf{C}\right)$} \\
\cline { 2 - 7 } & Simulated & Observed & Simulated & Observed & Simulated & Observed \\
\hline Range & $2.66-2.68$ & $2.34-2.66$ & $8.70-8.71$ & $7.60-8.50$ & $11.1-11.1$ & $10.5-11.2$ \\
(avg.) & $(2.67)$ & $(2.53)$ & $(8.71)$ & $(8.01)$ & $(11.1)$ & $(10.81)$ \\
\hline NBME & \multicolumn{2}{c}{$-5.08 \%$} & \multicolumn{2}{c}{$-8.28 \%$} & $-2.53 \%$ \\
\hline CV-RMSE & \multicolumn{2}{c}{$5.63 \%$} & \multicolumn{2}{c}{$9.14 \%$} & $3.20 \%$ \\
\hline
\end{tabular}

\subsection{Calibration of GSHP ch and GSHP $\mathrm{Pw}_{\mathrm{w}}$ at the Heat Recovery Operation for Cooling}

Figure 17 depicts simulation results and actual observations of the $\mathrm{EWT}_{\mathrm{ch}}$ and $\mathrm{LWT}_{\mathrm{ch}}$ of the $\mathrm{GSHP}_{\mathrm{ch}}$, and the $\mathrm{LWT}_{\mathrm{hw}}$ of the $\mathrm{GSHP}_{\mathrm{hw}}$, when both heat pumps operate at the heat recovery operation for cooling. Also $\mathrm{COP}_{\mathrm{cs}}$ and $\mathrm{COP}_{\mathrm{hws}}$ are calculated for the same period (Figure 18). NMBE and 
CV-RMSE for the same variables are listed up in Table 10, which of all values except for $\mathrm{COP}_{\mathrm{hws}}$ are within $\pm 5 \%$. All calculations started when all variables became rather stable, and then it lasts for an hour.

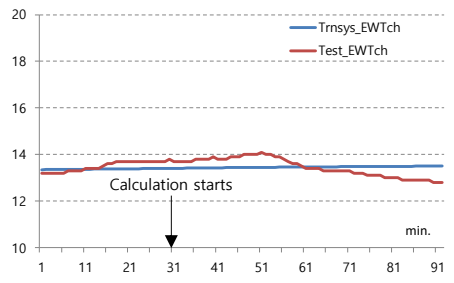

(a)

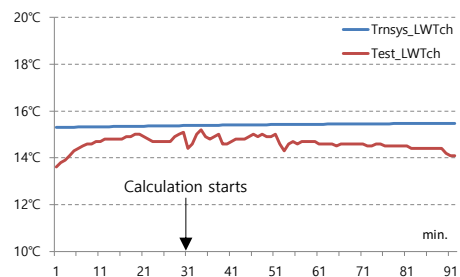

(b)

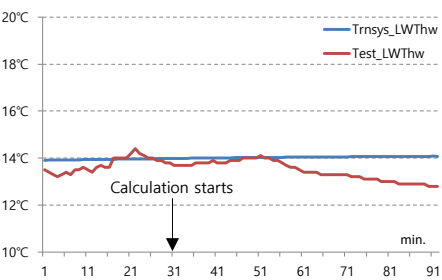

(c)

Figure 17. (a) $\mathrm{EWT}_{\mathrm{ch}}$ at the heat recovery operation for cooling; (b) $\mathrm{LWT}_{\mathrm{ch}}\left(=\mathrm{EWT}_{\mathrm{hw}}\right)$ at the heat recovery operation for cooling.; (c) $\mathrm{LWT}_{\mathrm{hw}}$ at the heat recovery operation for cooling.

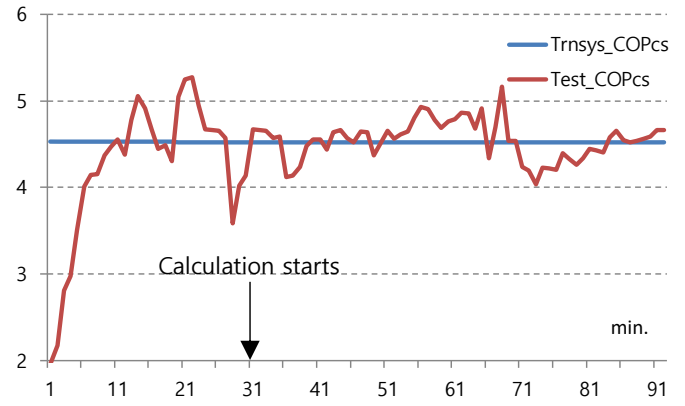

(a)

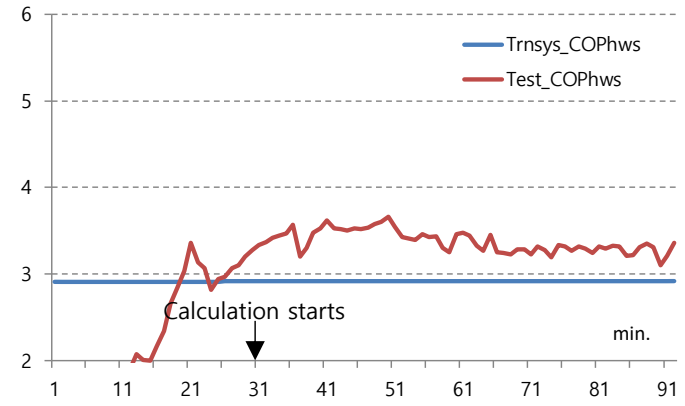

(b)

Figure 18. (a) $\mathrm{COP}_{\mathrm{cs}}$ at the heat recovery operation for cooling; (b) $\mathrm{COP}_{\mathrm{hws}}$ at the heat recovery operation for cooling.

Table 10. Simulated vs. Measured system COP, LWT and EWT of $\mathrm{GSHP}_{\mathrm{ch}}$ and $\mathrm{GSHP}_{\mathrm{hw}}$ at the heat recovery operation for cooling.

\begin{tabular}{|c|c|c|c|c|c|c|}
\hline \multirow{2}{*}{ Cooling } & \multicolumn{2}{|c|}{$\mathrm{COP}_{\mathrm{cs}}$ of $\mathrm{GSHP}_{\mathrm{ch}}$} & \multicolumn{2}{|c|}{$\mathrm{EWT}_{\mathrm{ch}}$ of $\mathrm{GSHP}_{\mathrm{ch}}$} & \multicolumn{2}{|c|}{$\mathrm{LWT}_{\mathrm{ch}}$ of $\mathrm{GSHP}_{\mathrm{ch}}$} \\
\hline & Simulated & Observed & Simulated & Observed & Simulated & Observed \\
\hline $\begin{array}{l}\text { Range } \\
\text { (avg.) }\end{array}$ & $\begin{array}{c}4.52-4.52 \\
(4.52)\end{array}$ & $\begin{array}{c}4.04-5.16 \\
(4.55)\end{array}$ & $\begin{array}{c}13.41-13.50 \\
(13.46)\end{array}$ & $\begin{array}{c}12.80-14.10 \\
(13.45)\end{array}$ & $\begin{array}{c}15.38-15.47 \\
(15.43)\end{array}$ & $\begin{array}{c}14.10-15.20 \\
\quad(14.62)\end{array}$ \\
\hline NBME & \multicolumn{2}{|c|}{$0.59 \%$} & \multicolumn{2}{|c|}{$-0.05 \%$} & \multicolumn{2}{|c|}{$-5.54 \%$} \\
\hline CV-RMSE & \multicolumn{2}{|c|}{$4.86 \%$} & \multicolumn{2}{|c|}{$3.15 \%$} & \multicolumn{2}{|c|}{$5.79 \%$} \\
\hline \multirow{2}{*}{ SHW } & \multicolumn{2}{|c|}{$\mathrm{COP}_{\mathrm{hws}}$ of $\mathrm{GSHP}_{\mathrm{hw}}$} & \multicolumn{2}{|c|}{$\mathrm{EWT}_{\mathrm{hw}}$ of $\mathrm{GSHP}_{\mathrm{hw}}$} & \multicolumn{2}{|c|}{ LWT $_{h w}$ of GSHP $\mathbf{P}_{h w}$} \\
\hline & Simulated & Observed & Simulated & Observed & Simulated & Observed \\
\hline $\begin{array}{l}\text { Range } \\
\text { (avg.) }\end{array}$ & $\begin{array}{c}2.92-2.92 \\
(2.92)\end{array}$ & $\begin{array}{c}3.10-3.66 \\
(3.37)\end{array}$ & $\begin{array}{c}15.38-15.47 \\
(15.43)\end{array}$ & $\begin{array}{c}14.10-15.20 \\
(14.62)\end{array}$ & $\begin{array}{c}13.98-14.08 \\
(14.04)\end{array}$ & $\begin{array}{c}12.80-14.10 \\
(13.45)\end{array}$ \\
\hline NBME & \multicolumn{2}{|c|}{$13.56 \%$} & \multicolumn{2}{|c|}{$-5.54 \%$} & \multicolumn{2}{|c|}{$-4.43 \%$} \\
\hline CV-RMSE & \multicolumn{2}{|c|}{$14.06 \%$} & \multicolumn{2}{|c|}{$5.79 \%$} & \multicolumn{2}{|c|}{$5.35 \%$} \\
\hline
\end{tabular}

\subsection{Calibration of $G_{S S H}$ ch and $G S H P_{h w}$ at the Concurrent Operation for Heating}

Figure 19 depicts simulation results and actual observations of $\mathrm{EWT}_{\mathrm{ch}}$ and $\mathrm{LWT}_{\mathrm{ch}}$ of the GSHP $\mathrm{Ch}_{\mathrm{ch}}$ and $\mathrm{LWT}_{\mathrm{hw}}$ of $\mathrm{GSHP}_{\mathrm{hw}}$ when both heat pumps operate at the concurrent operation for heating. Also $\mathrm{COP}_{\mathrm{cs}}$ and $\mathrm{COP}_{\mathrm{hws}}$ are calculated for the same period (Figure 20). NMBE and CV-RMSE for the same variables are listed up in Table 11, which of all values are within $\pm 7 \%$. All calculations started when all variables became stable, and then it lasts for an hour. 


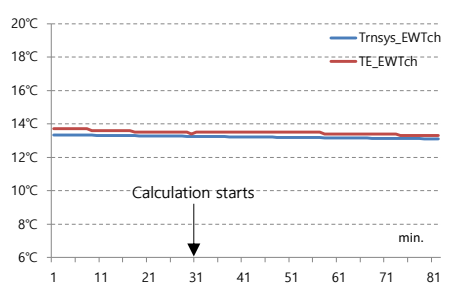

(a)

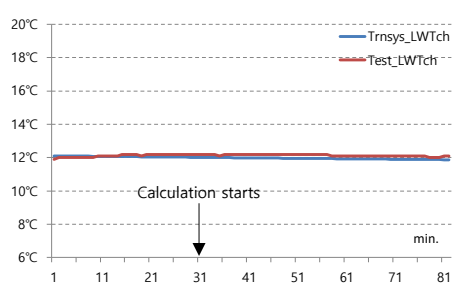

(b)

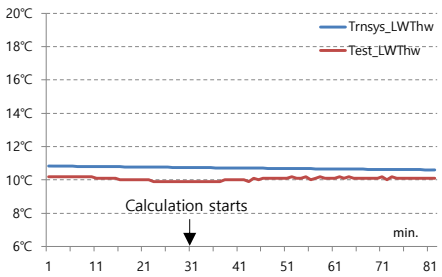

(c)

Figure 19. (a) $\mathrm{EWT}_{\mathrm{ch}}$ at the concurrent operation for heating; (b) $\mathrm{LWT}_{\mathrm{ch}}\left(=\mathrm{EWT}_{\mathrm{hw}}\right)$ at the concurrent operation for heating; (c) $\mathrm{LWT}_{\mathrm{hw}}$ at the concurrent operation for heating.

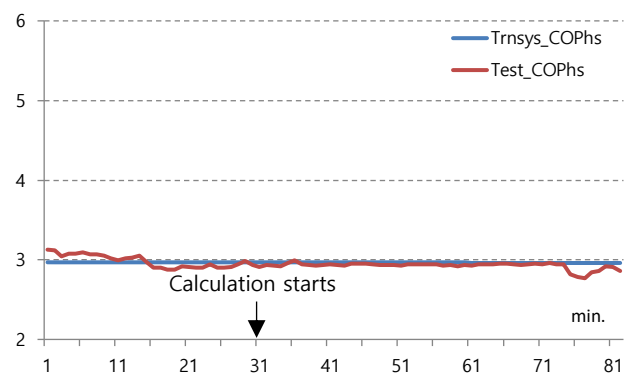

(a)

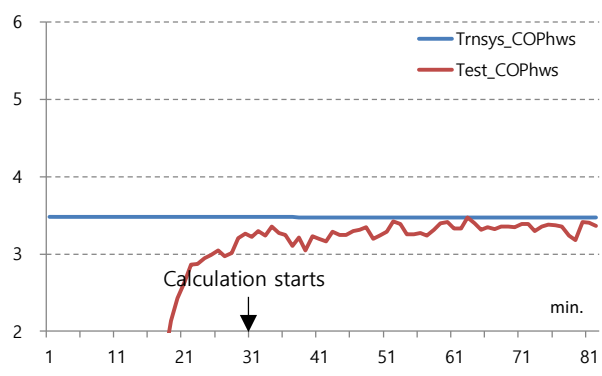

(b)

Figure 20. (a) $\mathrm{COP}_{\mathrm{hs}}$ at the concurrent operation for heating; (b) $\mathrm{COP}_{\mathrm{hws}}$ at the concurrent operation for heating.

Table 11. Simulated vs. measured system COP, EWT and LWT of $\mathrm{GSHP}_{\text {ch }}$ and $\mathrm{GSHP}_{\mathrm{hw}}$ at the concurrent operation for heating.

\begin{tabular}{|c|c|c|c|c|c|c|}
\hline \multirow{2}{*}{ Heating } & \multicolumn{2}{|c|}{$\mathrm{COP}_{\mathrm{hs}}$ of $\mathrm{GSHP}_{\mathrm{ch}}$} & \multicolumn{2}{|c|}{$\mathrm{EWT}_{\mathrm{ch}}$ of $\mathrm{GSHP}_{\mathrm{ch}}$} & \multicolumn{2}{|c|}{$\mathrm{LWT}_{\mathrm{ch}}$ of GSHP $\mathrm{ch}$} \\
\hline & Simulated & Observed & Simulated & Observed & Simulated & Observed \\
\hline $\begin{array}{l}\text { Range } \\
\text { (avg.) }\end{array}$ & $\begin{array}{c}2.96-2.97 \\
(2.97)\end{array}$ & $\begin{array}{l}2.77-3.00 \\
(2.93)\end{array}$ & $\begin{array}{c}13.11-13.25 \\
(13.18)\end{array}$ & $\begin{array}{c}13.30-13.50 \\
(13.43)\end{array}$ & $\begin{array}{c}11.88-12.02 \\
(11.94)\end{array}$ & $\begin{array}{c}12.00-12.20 \\
(12.15)\end{array}$ \\
\hline NBME & \multicolumn{2}{|c|}{$-1.32 \%$} & \multicolumn{2}{|c|}{$1.92 \%$} & \multicolumn{2}{|c|}{$1.65 \%$} \\
\hline CV-RMSE & \multicolumn{2}{|c|}{$1.90 \%$} & \multicolumn{2}{|c|}{$1.94 \%$} & \multicolumn{2}{|c|}{$1.68 \%$} \\
\hline \multirow{2}{*}{ SHW } & \multicolumn{2}{|c|}{$\mathrm{COP}_{\mathrm{hws}}$ of $\mathrm{GSHP}_{\mathrm{hw}}$} & \multicolumn{2}{|c|}{$\mathrm{EWT}_{\mathrm{hw}}$ of $\mathrm{GSHP}_{\mathrm{hw}}$} & \multicolumn{2}{|c|}{ LWT $_{\text {hw }}$ of GSHP $\mathrm{Gw}_{\mathrm{hw}}$} \\
\hline & Simulated & Observed & Simulated & Observed & Simulated & Observed \\
\hline $\begin{array}{l}\text { Range } \\
\text { (avg.) }\end{array}$ & $\begin{array}{c}3.47-3.48 \\
(3.47)\end{array}$ & $\begin{array}{c}3.05-3.47 \\
(3.30)\end{array}$ & $\begin{array}{c}11.88-12.02 \\
(11.94)\end{array}$ & $\begin{array}{c}12.00-12.20 \\
(12.15)\end{array}$ & $\begin{array}{c}10.61-10.75 \\
(10.67)\end{array}$ & $\begin{array}{c}9.90-10.20 \\
(10.06)\end{array}$ \\
\hline NBME & \multicolumn{2}{|c|}{$-5.24 \%$} & \multicolumn{2}{|c|}{$1.65 \%$} & \multicolumn{2}{|c|}{$-6.05 \%$} \\
\hline CV-RMSE & \multicolumn{2}{|c|}{$5.83 \%$} & \multicolumn{2}{|c|}{$1.68 \%$} & \multicolumn{2}{|c|}{$6.18 \%$} \\
\hline
\end{tabular}

\subsection{Calibration Discussion}

It should be noted that even though the discrepancy between measurement and simulated value for a variable (e.g., $\mathrm{COP}_{\mathrm{cs}}, \mathrm{COP}_{\mathrm{hws}}, \mathrm{LWT}_{\mathrm{hw}}$ as mentioned above) could be reduced, the discrepancy of other variables could be increased if we keep trying to decrease the discrepancy of individual variables excessively; for example, if NBME and CV-RMSE in case of the individual operation decrease by some percentage, then those in case of the heat recovery operation increase dramatically. Therefore, the model calibration was performed through "comprehensive" trials and errors, rather than focusing on several energy impacting variables. Such that, all variables eventually maintained reasonable tolerances in general.

In particular, the fluctuation between the measurement and simulated values for $\mathrm{GSHP}_{\mathrm{ch}}$ and $\mathrm{GSHP}_{\mathrm{hw}}$ is generally larger at the cooling mode (i.e., the heat recovery operation) than those at the 
heating mode (i.e., the concurrent operation). This result seems to be because in the cooling operation, the source side evaporator of $\mathrm{GSHP}_{\mathrm{hw}}$ uses the condensation heat of $\mathrm{GSHP}_{\mathrm{ch}}$, and as this makes $\mathrm{LWT}_{\mathrm{ch}}$ higher, the load control of the compressor and expansion valve of GSHP $\mathrm{ch}$ becomes somewhat unstable in the lower compression ratio region (which is generally used rarely), making all the flow rates more irregular.

Throughout cooling and heating tests by the integrated system, the major demand-side variables (i.e., the temperature and relative humidity of the indoor air, and the hot water supply temperature) were maintained almost constant within stable ranges as shown in Figure 21 a,b., e.g., $\pm 2{ }^{\circ} \mathrm{C}$ (room temperature), $\pm 3 \%$ (relative humidity), and $\pm 2{ }^{\circ} \mathrm{C}$ (hot water supply temperature), relative to the set point for each variable that are specified in the baseline model. A reasonably good synchronization between demand-side set points and observations signifies that the model has been properly calibrated, and the baseline model is a well configured for representing the physics of the integrated geothermal system.

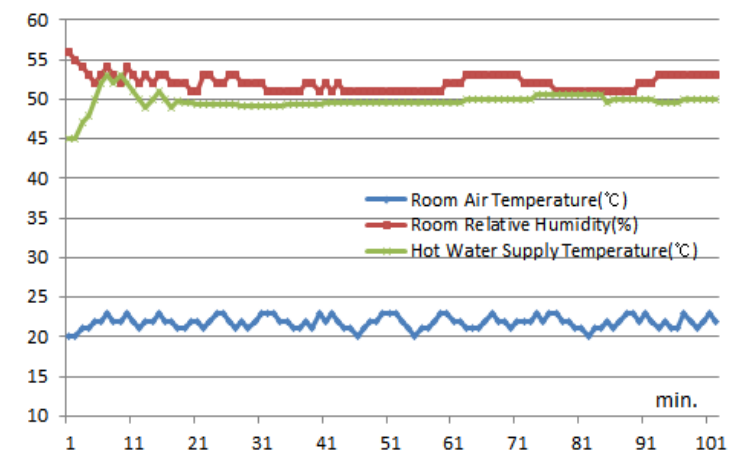

(a)

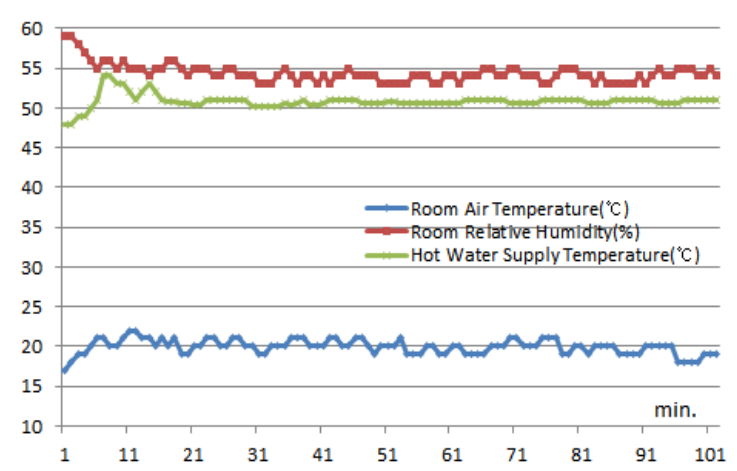

(b)

Figure 21. (a) Average room temperature, relative humidity and hot water temperature at the heat recovery operation for cooling; (b) Average room temperature, relative humidity and hot water temperature at the concurrent operation for heating.

Although simulated EWTs and LWTs of the integrated system in Figures 17 and 19 look rather inert due to their short observation term, the simulated $\mathrm{EWT}_{\mathrm{ch}}$ of $\mathrm{GSHP}_{\mathrm{ch}}$, for instance, tends to clearly increase in summer, and to clearly decrease in winter, as shown in long term TRNSYS results (Figures 22 and 23).

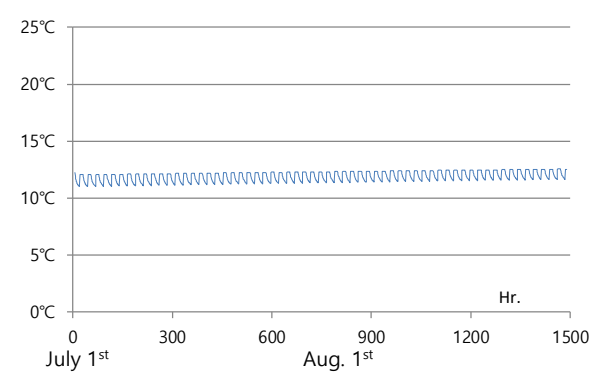

Figure 22. Simulated $\mathrm{EWT}_{\mathrm{ch}}$ sampled from July to Aug. 


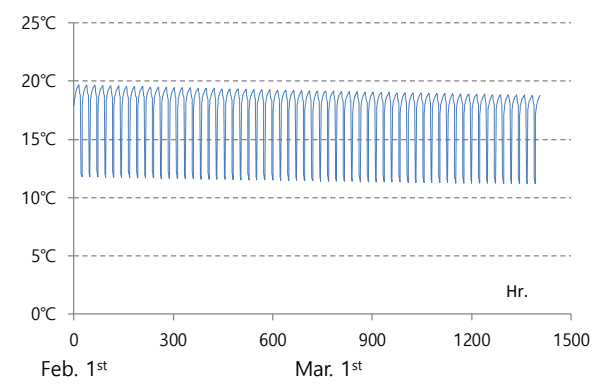

Figure 23. Simulated $\mathrm{EWT}_{\mathrm{ch}}$ sampled from Feb. to Mar.

\section{Comparative Analysis of Annual Electricity Use}

Simulation M\&V compares and analyzes the annual energy savings by the integrated system with respect to the conventional individual operation of $\mathrm{GSHP}_{\mathrm{ch}}$ and $\mathrm{GSHP}_{\mathrm{hw}}$. Cooling and heating seasons were determined according to the hotel's actual annual schedule. Then the annual electricity consumptions at both operations were estimated.

As described in Table 12, the total annual electricity for air-conditioning and SHW by the integrated geothermal system was saved by $19.1 \%$ in the cooling season, and saved by $9.6 \%$ in the heating season, compared to conventional individual operation. The integrated geothermal heat pump system is expected to have the largest energy savings when cooling demand and hot water supply demand occur simultaneously in summer. Therefore, the energy savings will be increased if the integrated geothermal heat pump system is applied to gyms, athletic facilities, and farms and agricultural facilities, which are typically at high demands for hot water. In heating seasons, however, about $10 \%$ of the expected electricity savings could not be so attractive for clients who need to make a large investment at the first place. As in heating season energy savings for SHW is relatively smaller than energy savings for heating, some advanced control measures seem to be considered for improving SHW supply efficiency in winter, such as sequence controls.

Table 12. Estimated annual electricity savings of $\mathrm{GSHP}_{\mathrm{ch}}$ and $\mathrm{GSHP}_{\mathrm{hw}}$ by the individual operation and the integrated operation.

\begin{tabular}{|c|c|c|c|}
\hline \multicolumn{2}{|c|}{ Heat Pump Operations } & $\begin{array}{c}\text { Cooling Season } \\
\text { (From May to Oct.) }\end{array}$ & $\begin{array}{c}\text { Heating Season } \\
\text { (From Nov. to Apr.) }\end{array}$ \\
\hline \multirow{3}{*}{$\begin{array}{l}\text { Individual operation of } \\
\mathrm{GSHP}_{\mathrm{ch}} \text { and GSHP } \\
\text { on its own ground loop }\end{array}$} & $\begin{array}{l}\text { For heating or cooling } \\
\qquad(\mathrm{kWh})\end{array}$ & $\begin{array}{l}69,693 \\
(100 \%)\end{array}$ & $\begin{array}{l}121,677 \\
(100 \%)\end{array}$ \\
\hline & $\begin{array}{l}\text { For service hot water } \\
\text { (kWh) }\end{array}$ & $\begin{array}{l}22,708 \\
(100 \%)\end{array}$ & $\begin{array}{l}34,901 \\
(100 \%)\end{array}$ \\
\hline & $\begin{array}{l}\text { Sum } \\
(\mathrm{kWh})\end{array}$ & $\begin{array}{l}92,401 \\
(100 \%)\end{array}$ & $\begin{array}{l}156,578 \\
(100 \%)\end{array}$ \\
\hline \multirow{3}{*}{$\begin{array}{l}\text { Integrated operation of } \\
\mathrm{GSHP}_{\mathrm{ch}} \text { and GSHP } \\
\text { on the shared ground loop }\end{array}$} & $\begin{array}{l}\text { For heating or cooling } \\
\qquad(\mathrm{kWh})\end{array}$ & $\begin{array}{c}55,274 \\
(79.3 \%)\end{array}$ & $\begin{array}{l}108,205 \\
(88.9 \%)\end{array}$ \\
\hline & $\begin{array}{l}\text { For service hot water } \\
\text { (kWh) }\end{array}$ & $\begin{array}{c}19,498 \\
(85.9 \%)\end{array}$ & $\begin{array}{c}33,320 \\
(95.5 \%)\end{array}$ \\
\hline & $\begin{array}{l}\text { Sum } \\
(\mathrm{kWh})\end{array}$ & $\begin{array}{c}74,772 \\
(80.9 \%)\end{array}$ & $\begin{array}{l}141,525 \\
(90.3 \%)\end{array}$ \\
\hline
\end{tabular}

The tests in this study were carried out in an actual hotel in a short semi-steady state period, and the annual electricity savings were estimated through the TRNSYS simulation-based M\&V calibrated with the measured data. In a future study, however, it may be necessary to do $M \& V$ again with longer term operation data. Furthermore, the system performance and COP could be improved if more precise automatic control is applied, and/or if more stable control in the hot water supply region of the low compression ratio can be achieved. 


\section{Conclusions}

This study proposes an integrated geothermal heat pump system that is composed of ground source heat pumps for air-conditioning and ground source heat pumps for service hot water, which share a ground water loop. It was installed in a hotel in South Korea for a pilot test. This study experimented on the heat recovery operation in which the ground source heat pump for service hot water recovers the waste heat from the condenser of the air-conditioning ground source heat pump, which is usually discarded into the ground in summer, and reuses it as a heat source for the evaporator. This study has also verified that the shared ground loop could be more advantageous in winter for both heat pumps in terms of shifting up the EWT range, and of saving pumping power than separated ground loops for each heat pump. The analysis results can be summarized as follows:

(1) During the cooling field test, the average system COP of the ground source heat pump for service hot water has improved (from 2.53) to 3.37, and the average system COP of the ground source heat pump for cooling improved (from 3.95) to 4.55. Additionally, during the heating field test, the average system COP of the ground source heat pump for service hot water improved (from 2.53) to 3.30, and the average system COP of the ground source heat pump for heating improved (from 2.85) to 2.93

(2) After simulation-based measurement and verification using the observed data from the actual hotel and system, the annual electricity use of the integrated geothermal heat pump system was analyzed; the total annual electricity savings was $19.1 \%$ in the cooling season and $9.6 \%$ in the heating season, with respect to the individual operation that does not share the ground water loop.

(3) The integrated geothermal heat pump system is expected to make the largest electricity savings when cooling demand and hot water supply demand occur simultaneously in summer. In winter, however, its estimated electricity savings may not be so attractive to investors.

By sharing a ground loop between heat pumps with different demands, the integrated geothermal system has a large potential to reduce the size of ground heat exchanger and annual electricity costs, if the different loads can be well-balanced. In this regard, in future study an economic analysis of the integrated system compared to legacy systems needs to be done. Concerning the load balance between space heating and hot water, additional energy saving measures for supplying service hot water need to be explored in terms of real-time monitoring, energy-saving automatic controls, and the operation strategy. In particular, future studies need to examine the possibility of improving the performance and efficiency by mitigating the state change rate of the working fluid (e.g., water and refrigerant) by applying more precise controls over the service hot water heat pump. Since the proposed system is a pilot product, however, a sufficiently longer testing duration should be secured first for stability before all new features are tried on it.

Author Contributions: Conceptualization, J.S.S. and J.W.P.; methodology, J.S.S.; software, J.S.S.; validation, J.S.S. and S.H.K.; formal analysis, J.S.S. and S.H.K.; investigation, J.S.S. and S.H.K.; resources, J.S.S. and J.W.P.; data curation, J.S.S.; writing-original draft preparation, J.S.S. and S.H.K.; writing-review and editing, J.S.S. and S.H.K.; visualization, J.S.S.; supervision, S.H.K.; project administration, J.S.S. and S.H.K.; funding acquisition, S.H.K. and J.W.P. All authors have read and agreed to the published version of the manuscript.

Funding: This study was supported by the Research Program funded by the Seoul National University of Science and Technology.

Conflicts of Interest: The authors declare no conflict of interest. 


\section{Nomenclature}

$\begin{array}{ll}\mathrm{GSHP}_{\mathrm{ch}} & \text { Ground Source Heat Pump for air-conditioning } \\ \mathrm{GSHP}_{\mathrm{hw}} & \text { Ground Source Heat Pump for service hot water } \\ \mathrm{COP}_{\mathrm{c}} & \text { Coefficient of Performance of } \mathrm{GSHP}_{\mathrm{ch}} \text { for cooling } \\ \mathrm{COP}_{\mathrm{h}} & \text { Coefficient of Performance of } \mathrm{GSHP}_{\mathrm{ch}} \text { for heating } \\ \mathrm{COP}_{\mathrm{cs}} & \text { System Coefficient of Performance of } \mathrm{GSHP}_{\mathrm{ch}} \text { for cooling including auxiliary power } \\ \mathrm{COP}_{\mathrm{hs}} & \text { System Coefficient of Performance of } \mathrm{GSHP}_{\mathrm{ch}} \text { for heating including auxiliary power } \\ \mathrm{COP}_{\mathrm{ch}} & \text { System Coefficient of Performance of } \mathrm{GSHP}_{\mathrm{ch}} \text { including auxiliary power } \\ \mathrm{COP}_{\mathrm{hw}} & \text { Coefficient of Performance of } \mathrm{GSHP}_{\mathrm{hw}} \\ \mathrm{COP}_{\mathrm{hws}} & \text { System Coefficient of Performance of } \mathrm{GSHP}_{\mathrm{hw}} \text { including auxiliary power } \\ \mathrm{EWT}_{\mathrm{ch}} & \text { Entering Water Temperature from ground heat exchanger to GSHP } \\ \mathrm{EWT}_{\mathrm{hw}} & \text { Entering Water Temperature from ground heat exchanger to GSHP } \\ \mathrm{LWT}_{\mathrm{hh}} & \text { Leaving Water Temperature from } \mathrm{GSHP}_{\mathrm{ch}} \text { to ground heat exchanger } \\ \mathrm{LWT}_{\mathrm{hw}} & \text { Leaving Water Temperature from } \mathrm{GSHP}_{\mathrm{hw}} \text { to ground heat exchanger } \\ \mathrm{SHW} & \text { Service Hot Water }\end{array}$

\section{References}

1. Yang, H.; Cui, P.; Fang, Z. Vertical-borehole ground-coupled heat pumps: A review of models and systems. Appl. Energy 2010, 87, 16-27. [CrossRef]

2. Man, Y.; Yang, H.; Wang, J. Study on hybrid ground-coupled heat pump system for air-conditioning in hot-weather areas like Hong Kong. Appl. Energy 2010, 87, 2826-2833. [CrossRef]

3. Fan, R.; Gao, Y.; Pan, Y.; Zhang, Y. Research on cool injection and extraction performance of borehole cool energy storage for ground coupled heat pump system. Energy Build. 2015, 101, 35-44. [CrossRef]

4. Liu, Z.; Li, Y.; Xu, W.; Yin, H.; Gao, J.; Jin, G.; Lun, L.; Jin, G. Performance and feasibility study of hybrid ground source heat pump system assisted with cooling tower for one office building based on one Shanghai case. Energy 2019, 173, 28-37. [CrossRef]

5. Zhai, X.; Qu, M.; Yu, X.; Yang, Y.; Wang, R. A review for the applications and integrated approaches of ground-coupled heat pump systems. Renew. Sustain. Energy Rev. 2011, 15, 3133-3140.

6. Emmi, G.; Zarrella, A.; De Carli, M.; Galgaro, A. Solar Assisted Ground Source Heat Pump in Cold Climates. Energy Procedia 2015, 82, 623-629. [CrossRef]

7. Bi, Y.; Guo, T.; Zhang, L.; Chen, L. Solar and ground source heat-pump system. Appl. Energy 2004, 78, 231-245. [CrossRef]

8. Rad, F.M.; Fung, A.S.; Leong, W.H. Feasibility of combined solar thermal and ground source heat pump systems in cold climate, Canada. Energy Build. 2013, 61, 224-232. [CrossRef]

9. Ozgener, O.; Hepbasli, A. Exergoeconomic analysis of a solar assisted ground-source heat pump greenhouse heating system. Appl. Therm. Eng. 2005, 25, 1459-1471. [CrossRef]

10. ICAX Interseasonal Heat Transfer, Shared Ground Loop, Retrieved. 2020. Available online: https: //www.icax.co.uk/Shared_Ground_Loop.html (accessed on 10 January 2020).

11. UK Office of Gas and Electricity Markets. Easy Guide to Shared Ground Loops for the Non-Domestic Renewable Heat Incentive (RHI). 2020. Available online: https://www.ofgem.gov.uk/publications-andupdates/easy-guide-shared-ground-loops-non-domestic-renewable-heat-incentive-rhi (accessed on 10 January 2020).

12. Alavy, M.; Dworkin, S.B.; Leong, W.H. A design methodology and analysis of combining multiple buildings onto a single district hybrid ground source heat pump system. Renew. Energy 2014, 66, 515-522. [CrossRef]

13. Almerbati, A.; Lorente, S.; Bejan, A. Energy design for dense neighborhoods: One heat pump rejects heat, the other absorbs heat from the same loop. Int. J. Therm. Sci. 2015, 96, 227-235. [CrossRef]

14. Paludetto, D.; Lorente, S. Modeling the heat exchanges between a datacenter and neighboring buildings through an underground loop. Renew. Energy 2016, 93, 502-509. [CrossRef]

15. Choi, J.M.; Park, Y.-J.; Kang, S.-H. Temperature distribution and performance of ground-coupled multi-heat pump systems for a greenhouse. Renew. Energy 2014, 65, 49-55. [CrossRef] 
16. Jung, Y.-J.; Kim, H.-J.; Choi, B.-E.; Jo, J.-H.; Cho, Y.-H. A Study on the efficiency improvement of multi-geothermal heat pump systems in korea using coefficient of performance. Energies 2016, 9, 356. [CrossRef]

17. Shin, J.-H.; Kim, Y.-I.; Cho, Y.-H. Development of operating method of multi-geothermal heat pump systems using variable water flow rate control and a COP prediction model based on ANN. Energies 2019, 12, 3894. [CrossRef]

18. Kjellsson, E.; Hellström, G.; Perers, B. Optimization of systems with the combination of ground-source heat pump and solar collectors in dwellings. Energy 2010, 35, 2667-2673. [CrossRef]

19. Jouhara, H.; Khordehgah, N.; AlMahmoud, S.; Delpech, B.; Chauhan, A.; Tassou, S.A. Waste heat recovery technologies and applications. Therm. Sci. Eng. Prog. 2018, 6, 268-289. [CrossRef]

20. Baradey, Y.; Hawlader, M.N.A.; Ismail, A.; Hrairi, M. Waste heat recovery in heat pump systems: Solution to reduce global warming. IIUM Eng. J. 2015, 16, 31-42. [CrossRef]

21. Van De Bor, D.; Ferreira, C.A.I.; Kiss, A.A. Low grade waste heat recovery using heat pumps and power cycles. Energy 2015, 89, 864-873. [CrossRef]

22. FEMP. MEV Guidelines: Measurement and Verification for Federal Energy Projects Version 3.0; Technical report for: U.S. Department of Energy Federal Energy Management Program, M\&V Guideline; Office of Energy Efficiency and Renewable Energy: Washington, DC, USA, April 2008. Available online: https: //www.hud.gov/sites/documents/DOC_10604.PDF (accessed on 25 October 2019).

23. ASHRAE. Measurement of Energy and Demand Savings; Technical Report for American Society of Heating, Refrigerating, and Air-Conditioning Engineers, ASHRAE Guideline 14; ASHRAE Inc.: Atlanta, GA, USA, June 2002.

24. IPMVP. Concepts and Options for Determining Energy and Water Savings; Technical Report for Efficiency Valuation Organization; Efficiency Valuation Organization: Washington, DC, USA, 2015; Volume 1.

25. Thermal Dynamics Inc. GLD Software.10.0; Thermal Dynamics Inc.: Maple Plain, MN, USA, 2019; Available online: https://www.groundloopdesign.com/ (accessed on 25 October 2019).

26. Thermal Energy System Specialists, TRNSYS. 17; Thermal Energy System Specialists, LLC: Madison, WI, USA, 2019; Available online: http://www.trnsys.com (accessed on 15 July 2019).

27. Burman, E.; Mumovic, D.; Kimpian, J. Towards measurement and verification of energy performance under the framework of the European directive for energy performance of buildings. Energy 2014, 77, 153-163. [CrossRef]

28. Granderson, J.; Touzani, S.; Custodio, C.; Sohn, M.D.; Jump, D.; Fernandes, S. Accuracy of automated measurement and verification $(\mathrm{M} \& \mathrm{~V})$ techniques for energy savings in commercial buildings. Appl. Energy 2016, 173, 296-308.

(C) 2020 by the authors. Licensee MDPI, Basel, Switzerland. This article is an open access article distributed under the terms and conditions of the Creative Commons Attribution (CC BY) license (http://creativecommons.org/licenses/by/4.0/). 